UDC 573.3

Yu. M. Yevdokimov, V. I. Salyanov, S. G. Skuridin

\title{
DNA LIQUID-CRYSTALLINE DISPERSION PARTICLES AS A PLATFORM FOR CREATION OF "RIGID" SPATIAL STRUCTURES
}

Engelhardt Institute of Molecular Biology of the Russian Academy of Sciences, 32 Vavilova St., Moscow, 119991, Russia. E-mail: yevdokim@eimb.ru

The properties of double-stranded DNA liquid-crystalline dispersion particles formed as a result of the phase exclusion of these molecules from water-salt solutions of poly(ethyleneglycol) are considered. For the first time a generalized approach to the creation of "rigid" particles (nanoobjects) from DNA liquid-crystalline dispersion particles was formulated. It is based on the joining all DNA molecules forming a single dispersion particle as a result of sharp decrease in their solubility and formation of the high-molecular mass, integrated (gel-like, "rigid") structure. The physicochemical variants of this approach include sharp decrease in solubility of adjacent double-stranded DNA molecules ordered in quasi-nematic layers of liquid-crystalline dispersion particle due to their "salting-out" under action of cations of rare earth elements, or "cross-linking" of neighboring DNA molecules by synthetic nanobridges consisting of alternating molecules of an antibiotic daunomycin and bivalent copper ions. The nanotechnological variant is based on incorporation of small size gold nanoparticles in "free" space between DNA molecules, which are ordered in quasi-nematic layers of liquidcrystalline dispersion particle. This process results in creation of gold clusters in "free" space between adjacent DNA molecules. It is accompanied by increase of interaction between DNA molecules via gold nanoparticles and by decrease in a solubility of dispersion particle. The formed high molecular mass "rigid" structures are incompatible with the initial aqueous polymeric solution and have unique properties. Practical application of "rigid" DNA particles for medicine and biosensorics is demonstrated.

Key words: double-stranded DNA, DNA liquid-crystalline dispersions, DNA-based nanostructures, circular dichroism, absorption spectroscopy, atomic force microscopy, small-angle X-ray scattering, gadolinium ions, crosslinks, synthetic nanobridges, gold nanoparticles, neutron capture therapy, biosensors.

DOI: $10.18083 /$ LCAppl.2017.4.6

Ю. М. Евдокимов, В. И. Салянов, С. Г. Скуридин

\section{ЧАСТИЦЫ ЖИДКОКРИСТАЛЛИЧЕСКИХ ДИСПЕРСИЙ ДНК КАК ПЛАТФОРМА ДЛЯ СОЗДАНИЯ «ЖЕСТКИХ» ПРОСТРАНСТВЕННЫХ СТРУКТУР}

Институт молекулярной биологии им. В. А. Энгельгардта Российской академии наук, ул. Вавилова, 32, 119991 Москва, Россия. E-mail: yevdokim@eimb.ru

В обзоре сформулирован общий подход к созданию «жестких» пространственных структур (нанообъектов) с использованием частии жидкокристаллических дисперсий двухиепочечной ДНК $u$ синтетических полинуклеотидов, образующихся в водно-солевых растворах нейтрального полимера полиэтиленглиоля. Этот подход основан на учете понижения растворимости молекул ДНК, образующих частииу дисперсии, приводящей к их объединению и формированию интегрированной (гелеобразной) «жесткой» высокомолекулярной структуры. Физико-химические варианты данного подхода включают понижение растворимости двухцепочечных молекул ДНК, упорядоченных в квазинематических слоях частищы жидкокристаллической дисперсии, вследствие их «высаливания» под действием катионов редкоземельных элементов или «сшивания» в результате создания искусственных наномостиков, состоящих из чередующихся молекул антибиотика антрациклиновой группы - дауномицина и ионов

(C) Yevdokimov Yu. M., Salyanov V. I., Skuridin S. G., 2017 
двухвалентной меди. Нанотехнологический вариант предлагаемого подхода основан на инкорпораџии наночастии золота малого размера ( 2 нм) в «свободное» пространство между молекулами ДНК, упорядоченными в квазинематических слоях частицы жидкокристаллической дисперсии. Этот процесс приводит к формированию линейных кластеров из наночастии золота между соседними молекулами ДНК. Образование кластеров сопровождается увеличением взаимодействия между молекулами ДНК и как следствие этого понижением растворимости частии жидкокристаллической дисперсии. Полученные при помощи разработанного подхода «жесткие» пространственные структуры ДНК (нанообъекты) несовместимы с исходным водно-полимерным раствором и обладают уникальными физико-химическими свойствами. Продемонстрирована возможность практического использования этих структур в области биосенсорики и медищине.

Ключевые слова: двухиепочечная ДНК, жидкокристаллические дисперсии ДНК, наноструктуры на основе ДНК, круговой дихроизм, спектроскопия поглощения, атомно-силовая микроскопия, малоугловое рассеяние рентгеновых лучей, ионы гадолиния, сшивки, синтетические наномостики, наночастищы золота, нейтрон-захватная терапия, биосенсорика.

\section{Some parameters and properties of the DNA liquid-crystalline dispersion particles formed in aqueous-salt-poly(ethyleneglycol) solutions}

It is known that the phase exclusion of rigid, linear, double-stranded (ds) DNA molecules with a molecular mass smaller than $1 \times 10^{6} \mathrm{Da}$ from the aqueous salt solutions of some polymers, for instance, poly(ethyleneglycol) (PEG), is accompanied by the formation of nucleic acid (NA) dispersions. The phase exclusion efficiency depends on a number of factors indicated in Fig. 1. Two factors, the molecular mass and solubility of ds DNA molecules, are especially important. The higher the molecular mass of DNA, the lower the compatibility of this molecule with the PEG solution, and the higher the phase exclusion efficiency. The lower the solubility of DNA molecules, the higher their immiscibility with a PEG solution and the higher the phase exclusion efficiency.

Each dispersion particle can be conventionally treated as a drop of a concentrated DNA solution. The structure and properties of the dispersion particle are determined, in addition to the ionic strength, $\mathrm{pH}$ and temperature of the solution, by its "critical" osmotic pressure $[1,2]$.

A dispersion particle cannot be taken in hand, seen or placed on the surface of a membrane filter since, in the absence of the "critical" osmotic pressure of the solution, the spatial DNA molecule packing must change so that the DNA molecules will transform from the condensed state into the initial isotropic one.

Theoretical estimates based on the application of various methods (sedimentation analysis, scattering of UV irradiation, dynamic light scattering, etc.) have shown that for ds DNA molecules with the molecular mass $(0.6-0.8) \times 10^{6} \mathrm{Da}$, the mean diameter of dispersion particles is close to $500 \mathrm{~nm}$. The molecular mass of one dispersion particle reaches $\sim 10^{10} \mathrm{Da}$, i.e., a particle contains approximately $10^{4}$ DNA molecules $[3,4]$.

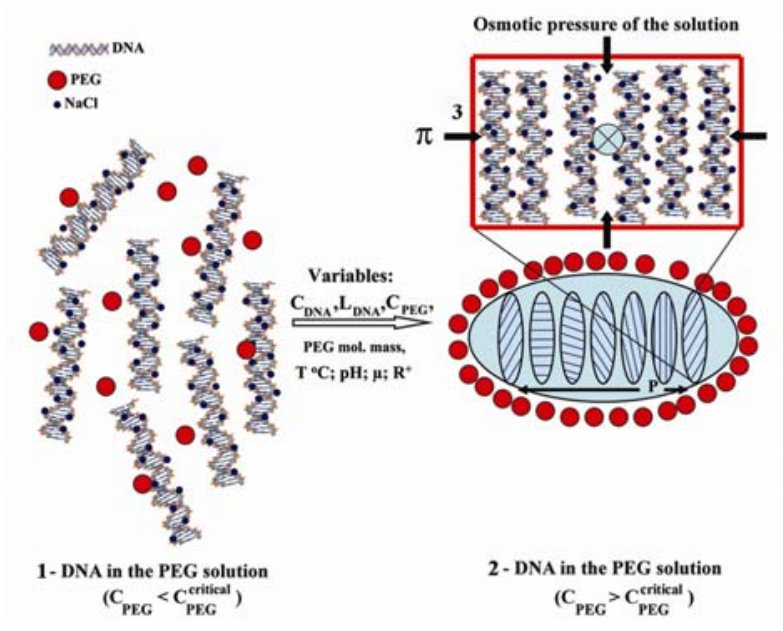

Fig. 1. Formation of a liquid-crystalline dispersion as a result of phase exclusion of linear double stranded DNA molecules with a molecular mass of $(6-8) \times 10^{5} \mathrm{Da}$ from a PEG-containing aqueous salt solution [3]:

1 - ds DNA molecules at a PEG concentration in solution below the "critical" value, 2 - A particle of DNA liquid-crystalline dispersion formed at a PEG concentration above the "critical" value ( $\mathrm{P}$ is the pith of the helical twist of the spatial structure of a dispersion particle), 3 - A quasinematic layer of DNA molecules (the cross $(\otimes)$ at the center denotes the rotation axis of the helical structure; the rectangular box and arrows correspond to the osmotic pressure (П) of a PEG-containing solution) 
Dispersion particles have several characteristic features. First, a polymer is not contained in dispersion particles. Second, neighboring DNA molecules are separated by a distance of $2.5-5.0 \mathrm{~nm}$, i.e., particles have properties typical for crystals. Third, the concentration of DNA in dispersion particles (or packing density of DNA molecules) is very high and it depends on osmotic pressure of PEG-containing solution (or PEG concentration in solution). For instance, at $\mathrm{C}_{\mathrm{PEG}}=170 \mathrm{mg} / \mathrm{ml} \mathrm{C} \mathrm{C}_{\mathrm{DNA}}$ is equal to $299.98 \mathrm{mg} / \mathrm{ml}$; at $\mathrm{C}_{\mathrm{PEG}}=300 \mathrm{mg} / \mathrm{ml} \mathrm{C}_{\mathrm{DNA}}$ is equal to $484=\mathrm{mg} / \mathrm{ml}$.

We can accept that the maximal density of ds DNA molecules in the dispersion particles can be achieved at their hexagonal packing [5-7]. However, this packing (Fig. 2) does not correspond to structure of a true crystal, because there are disordered water molecules between the ds DNA molecules. The ds DNA molecules possess some disorder around their positions; they can slide and bend with respect to each other, as well as rotating around their long axis. This corresponds to the "liquid" character of the ds DNA molecules packing. These facts allow one to describe such particles using the term "liquid-crystalline dispersion (LCD) DNA particle".

Fig. 3 shows image of DNA molecules (Bform) spatial packing in a LCD particle [8]. These images were obtained by computer simulation based on the results of the analysis of the experimental small angle X-ray scattering curves from DNA phases formed at concentrating of dispersion particles due to low-speed centrifugation.

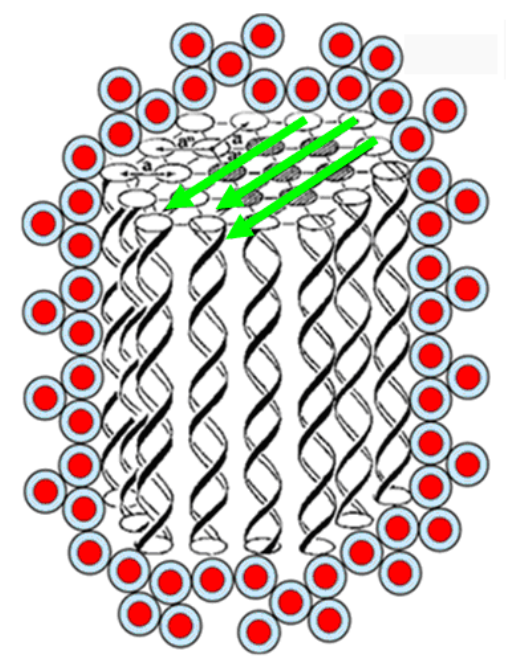

Fig. 2. Hypothetical scheme of the hexagonal packing of linear ds DNA molecules in a dispersion particle formed in an aqueous salt PEG solution [8]:

- Schematic images of PEG molecules; the arrows indicate the quasinematic layers of DNA molecules. The three main directions of the hexagonal array permit one to define quasinematic layers in the structure. Arrows show one type of layers. Quasinematic layers, even with a constant distance between them, can be rotated by a small angle with a change in the osmotic pressure or temperature, which leads to the formation of a spatially twisted (cholesteric) structure with abnormal optical activity
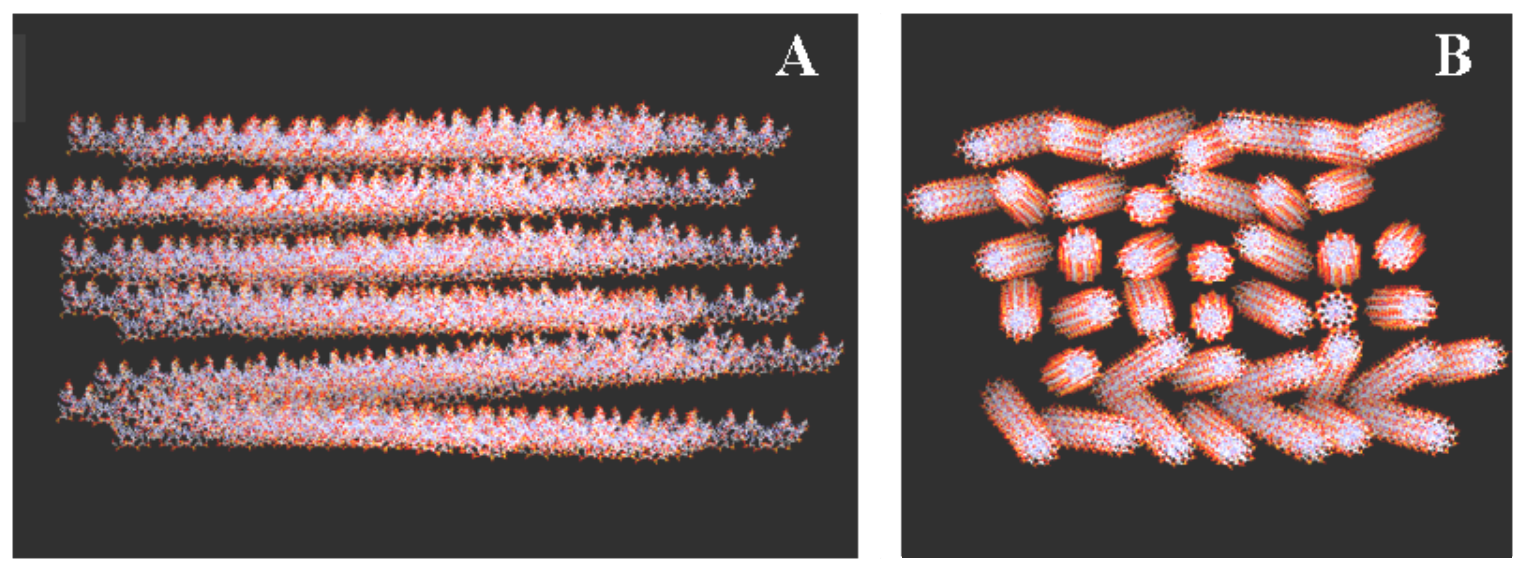

Fig. 3. Image of the spatial packing of DNA molecules (B-form) in a LCD particle (side view (A) and front view (B)) obtained by computer simulation [8] 
The minimization of the excluded volume of neighboring linear, rigid, ds DNA molecules induces the parallel, unidirectional (nematic-like) alignment of ds DNA molecules in a so-called "quasinematic" layers (Fig. 2) [9-12]. The distance between ds DNA molecules is determined by a balance between repulsive intermolecular forces and the compressing osmotic pressure of the PEG solution. Besides, ds DNA molecules possess several levels of chirality (helical secondary structure of ds DNA molecules, helical distribution of counter-ions near the DNA surface as well as asymmetry of C-atoms in sugar residues). The chiral and anisotropic properties of ds DNA molecules favor helical twisting of neighboring molecules. In this case, unidirectional alignment of the ds DNA molecules in dispersion particles competes with the tendency of these molecules to form a spatially twisted (cholesteric) structure.

All these properties of DNA LCDs were taken into account in the development of the phenomenological theory of circular dichroism (CD) of small-size LCD particles [13]. This theory described and predicted many features of the CD spectra of DNA LCD particles. The formed DNA LCDs are "colored" because DNA molecules contain chromophores (nitrogen bases) that absorb UV irradiation. In this case, theory $[13,14]$ predicts an appearance of an intense (abnormal) band in the CD spectrum located in the region of absorption of the ds DNA chromophores (nitrogen bases). The presence of this band is the univocal indication of the macroscopic (cholesteric) twist in the orientation of quasinematic layers formed by ds DNA molecules with a characteristic spatial pitch $(\mathrm{P})$. The $\mathrm{P}$ value typical of ds DNA cholesterics is about $2500 \mathrm{~nm}$ and the twist angle between quasinematic layers is equal to $0.5^{\circ}$. Hence, the terms "cholesteric liquid-crystalline dispersion (CLCD)" or "DNA cholesterics" have been used to describe this disperse system $[3,13]$.

The analysis of the dependence of an abnormal band in the CD spectrum upon PEG concentration (or osmotic pressure of PEG solution) in solutions used for DNA phase exclusion allows one to discriminate different structural states (phases) of DNA molecules (Fig. 4). The comparison of the structural parameters of the phases obtained after low-speed centrifugation of ds DNA particles (Table) and calculated above DNA concentrations to well-known parameters of the liquid-crystalline (LC) phases formed as a result of increase in ds DNA concentration in aqueous salt solutions and presented in Table 6 of [7] allows one to assume two modes of ds DNA molecule packing in dispersion particles. Namely, at osmotic pressure from 1 to 10 atm there is the twisted (cholesteric-like) packing of ds DNA molecules. For these dispersion particles an abnormal optical activity is typical (Fig. 4). At osmotic pressure more then that of $10 \mathrm{~atm}$ (PEG concentrations $\sim 240-300 \mathrm{mg} / \mathrm{ml}$ ) there is unidirectional hexagonal alignment of ds DNA molecules. The hexagonal LC phase devoid of abnormal optical activity [7].

The above statements have been verified by the results obtained with the help of small-angle X-ray scattering (SAXS) and specific textures of thin layers typical of these phases [15].

Thus, studies of the physicochemical properties of DNA CLCD particles have given fairly detailed information on the conditions of their formation and factors that can be used to control their properties. This information provides the basis for approaches to the transformation of "liquid" DNA CLCD particles into "rigid" structures.

The goal of the present review is the consideration of various approaches to creation of rigid DNA constructions of practical importance in the frame-work of the general concept on low solubility of the integrated (gel-like) structure, which includes all DNA molecules in the content of dispersion particle. The transformation of "liquid" particles of the DNA LCD into gel-like ("rigid") structures seems to be very interesting from the physicochemical and very attractive from the practical stand-point. This is due to the fact that the resulting rigid particles could be characterized not only by an ordered structure with a regular arrangement of neighboring ds DNA molecules but also by the high reactivity toward chemical, including biologically active compounds (BACs). Such particles are used in bioengineering, biosensorics and medicine. 


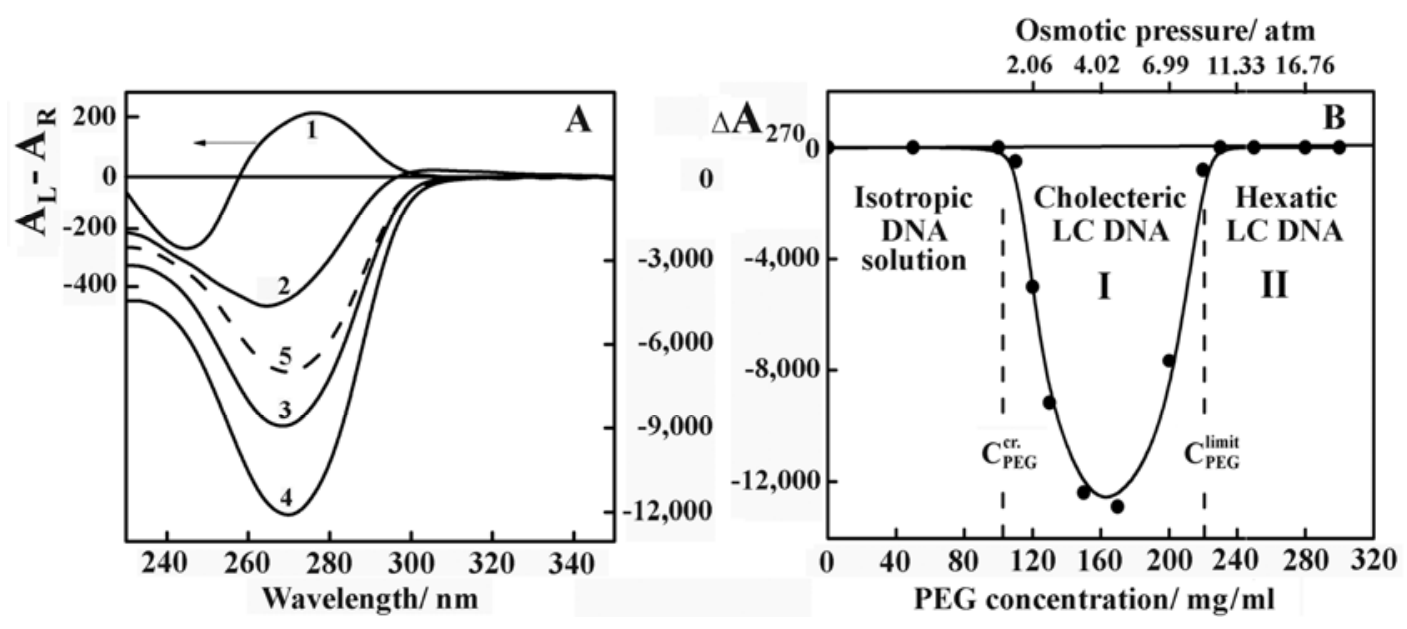

Fig. 4. A - The CD spectra of the aqueous salt solution of linear B-form DNA (curve 1, left ordinate) and DNA LCDs formed in aqueous salt solutions with different concentrations of PEG (curves 2-5, right ordinate) [15]:

$1-\mathrm{C}_{\mathrm{PEG}}=0,2-\mathrm{C}_{\mathrm{PEG}}=120 \mathrm{mg} / \mathrm{ml}(\Pi=2.062 \mathrm{~atm}), 3-\mathrm{C}_{\mathrm{PEG}}=130 \mathrm{mg} / \mathrm{ml}(\Pi=2.479 \mathrm{~atm}), 4-\mathrm{C}_{\mathrm{PEG}}=170 \mathrm{mg} / \mathrm{ml}(\Pi=4.616 \mathrm{~atm})$, $5-\mathrm{C}_{\mathrm{PEG}}=200 \mathrm{mg} / \mathrm{ml}(\Pi=6.987 \mathrm{~atm}) . \mathrm{C}_{\mathrm{DNA}}=30 \mu \mathrm{g} / \mathrm{ml}, 0.3 \mathrm{M} \mathrm{NaCl}+0.002 \mathrm{M} \mathrm{Na}^{+}$-phosphate buffer. $\Delta \mathrm{A}=\left(\mathrm{A}_{\mathrm{L}}-\mathrm{A}_{\mathrm{R}}\right) \times 10^{-6}$ optical units, $\mathrm{L}=1 \mathrm{~cm}, \mathrm{~T}=22^{\circ} \mathrm{C}$.

B - Dependence of the amplitude of the band in the CD spectra of DNA and DNA LCDs ( $\lambda=270 \mathrm{~nm})$ upon PEG concentration (the osmotic pressure of the PEG solutions are plotted on the upper abscissa, and the solution concentrations are indicated on the lower abscissa axis):

$\mathrm{C}_{\mathrm{DNA}}=30 \mu \mathrm{g} / \mathrm{ml}, 0.3 \mathrm{M} \mathrm{NaCl}+0.002 \mathrm{M} \mathrm{Na}^{+}$-phosphate buffer. $\Delta \mathrm{A}_{270} \times 10^{-6}$ optical units; $\mathrm{L}=1 \mathrm{~cm} ; \mathrm{T}=22{ }^{\circ} \mathrm{C}$. $\mathrm{C}_{\mathrm{PEG}}{ }^{\text {cr. }}$ and $\mathrm{C}_{\mathrm{PEG}}{ }^{\text {limit }}-$ the "critical" and the "limit" PEG concentrations, which necessary for existence of the DNA cholesteric LCDs, are shown

Table. Structural characteristics of the LC phases of DNA formed at different PEG concentrations

\begin{tabular}{|c|c|c|c|c|c|}
\hline $\begin{array}{c}\text { Sample } \\
\text { of DNA phase }\end{array}$ & $\begin{array}{c}s_{\max }, \mathrm{nm}^{-1} \\
( \pm 0.1 \mathrm{~nm}-1)\end{array}$ & $\begin{array}{c}\bar{d}, \mathrm{~nm} \\
( \pm 0.1 \mathrm{~nm})\end{array}$ & $\begin{array}{c}L, \mathrm{~nm} \\
( \pm 3.0 \mathrm{~nm})\end{array}$ & $\begin{array}{c}\Delta / \bar{d} \\
( \pm 0.01)\end{array}$ & $\begin{array}{c}S, \\
\text { the area under } \\
\text { the peak expressed } \\
\text { in relative units })\end{array}$ \\
\hline $\begin{array}{c}\text { Cholesteric LC } \\
\text { DNA } \\
(170 \mathrm{mg} / \mathrm{ml})\end{array}$ & 1.9 & 3.3 & 21 & 0.13 & 0.0070 \\
\hline $\begin{array}{c}\text { Hexatic } \\
\text { LC DNA }\end{array}$ & 2.3 & 2.7 & 91 & 0.07 & 0.0047 \\
\hline
\end{tabular}

Note: $s_{\max }-$ the wave vector $(\mathrm{s}=4 \pi \sin \theta / \lambda ; 2 \theta-$ the scattering angle; $\lambda-$ the X-ray wavelength equal

$0.1542 \mathrm{~nm}) ; \bar{d}$ - the periodicity of the structure (the interhelical distance); $L$ - the crystallite size; $\Delta / \bar{d}-$ the degree of disorder $(\Delta-$ the mean square deviation of distances between neighboring regularly packed structural elements; $\bar{d}$ - the periodicity of the structure (the interhelical distance)). Concentrations of PEG ( $\mathrm{mg} / \mathrm{ml}$; in parentheses) are indicated in the first column.

\section{Formation of "rigid" spatial structures from DNA LCD: Physicochemical approach}

When estimating the properties of liquid DNA particles, taking into account the polymer chemistry, one would note that only two variants (Fig. 5) of the physicochemical approach exist for preparing rigid spatial structures from DNA CLCD particles: (i) the salting out of DNA molecules ordered inside DNA CLCD particles (Fig. 5, B), and (ii) the cross-linking of neighboring DNA molecules inside DNA CLCD particles (Fig. 5, C). 


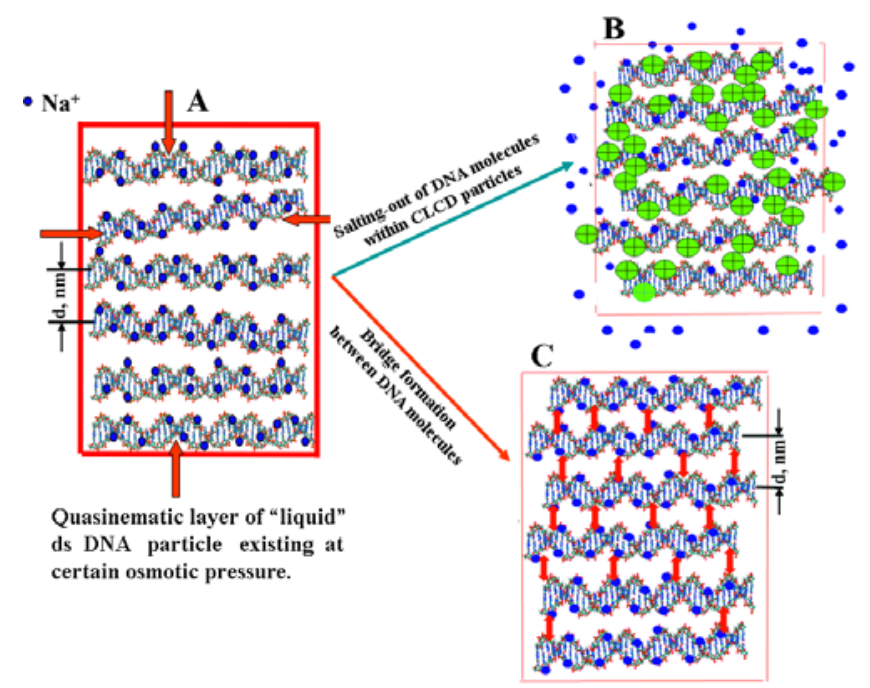

Fig. 5. A - Structure of quasinematic layer formed by ds DNA molecules in particle of LCD:

DNA molecules are ordered and the mean distance between these molecules is expressed as d value, which depends on osmotic pressure of solvent (thick red frame is symbol of osmotic pressure). Between DNA molecules there is a "free" space. The low molecular mass chemicals or BACs ("guests") can easily diffuse from outside into "free" space of quasinematic layers.

B - Hypothetical scheme of transformation of a liquid structure of quasinematic layer formed by ds DNA olecules into rigid state as a result of salting-out of these molecules:

The multivalent cations ( $\mathrm{R}^{\mathrm{N}+}$, "guests") diffuse into layer and form insoluble complexes with the DNA phosphate groups. Concentration of sodium cations is decreased, but concentration of "guests" is sharply increased in a quasinematic layer. Close approaching of all insoluble ds DNA molecules results in formation of integrated DNA structure, which can exist at low (if any) osmotic pressure of the solvent (shown as thin red frame).

C - Hypothetical scheme of transformation of a liquid structure of quasinematic layer formed by ds DNA molecules into a rigid state:

The crosslinks (nanobridges) are formed both between DNA molecules in one and neighboring quasinematic layers. At certain nanobridges amount and their rigidity the integrated structure that includes all ds DNA molecules is formed. The formed rigid spatial structure is capable of existing under a very low osmotic pressure of solution (shown as thin red frame)

\section{Salting-out of DNA molecules inside CLCD particles}

One can note, that the most useful method to determine the character of ds DNA molecule packing within small-size CLCD particles at their small concentration in PEG- containing solutions is circular dichroism (Fig. 4) [13].

Fig. 5, $B$ illustrates the results of the first approach [16] to the formation of rigid DNA particles. The idea of the first variant to the design of rigid DNA particles has been formulated as follows:

The neighboring ds DNA molecules with phosphate groups neutralized by sodium cations are resided in quasinematic layers of CLCD particles in the "dissolved" state, and there is free space between them. Multiply charged cations can diffuse in this free space, displace sodium cations from the hydration shell of DNA and efficiently neutralize the negative charges of the DNA phosphate groups. It is accompanied by drastically lowering the solubility of DNA molecules (so-called "DNA salting-out"). The interaction even between poorly soluble neighboring (ds DNA-multiply charged cation) complexes can lead to the formation of an integrated, (gel-like), structure involving all DNA molecules ordered in the quasinematic layers of the CLCD particle. This very high-molecular mass, gel-like ("rigid") structure is incompatible with a PEG solution and can exist in the absence of the osmotic pressure of the PEG-containing solution".

From the physicochemical point of view, this approach is based on the initiation of gelation of DNA molecules. Such process should occur inside a nanometer-sized CLCD particle as a result of the decrease in the solubility of all ds DNA molecules.

For salting-out ds DNA molecules in the quasinematic layers of CLCD particles, multiply charged lanthanide cations are of special interest [17, 18]. Such cations efficiently neutralize the negative charges of the DNA phosphate groups, the complexes of the cations with the phosphate groups being nearly insoluble (for example, the solubility constant of gadolinium phosphate is $\sim 10^{-12} \mathrm{M}$ ). 
Taking into account the possible practical use of the resulting rigid structures, gadolinium salts (in particular, $\mathrm{GdCl}_{3}$ ) have been selected as the source of a basic multi-charged cation.

It was shown $[17,19]$ that the amplitude of the negative abnormal band in the CD spectrum of the cholesteric DNA LCD formed in PEG-containing solution increases at a high gadolinium concentration, at which $\mathrm{Na}^{+}$ions are replaced by gadolinium $\left(\mathrm{Gd}^{3+}\right)$ cations in nearest environment of ds DNA molecules (Fig. 6).

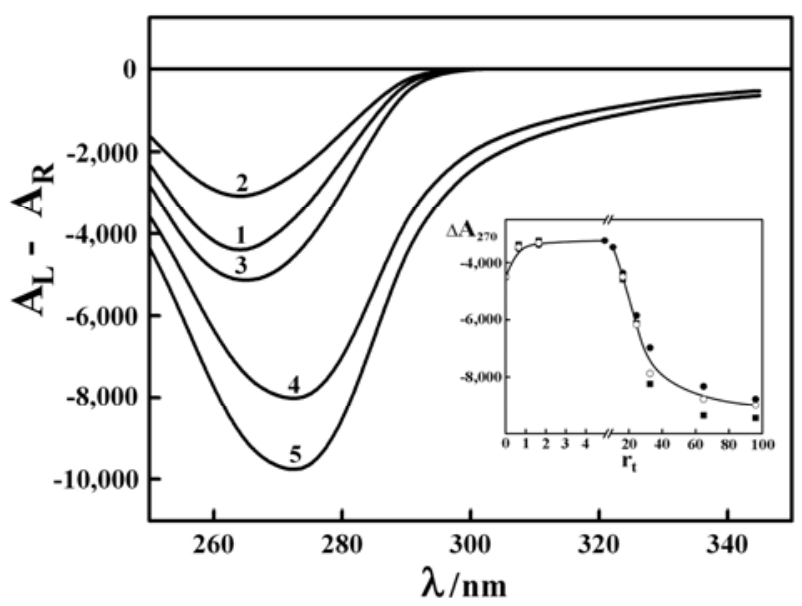

Fig. 6. The CD spectra of the ds DNA CLCD in the absence and presence of $\mathrm{GdCl}_{3}$ in solution [3]:

1 - initial CLCD of ds DNA $\left(\mathrm{C}_{\mathrm{GdCl}}=0\right) ; 2-0.025 \mathrm{mM}$; $3-0.5 \mathrm{mM} ; 4-1.0 \mathrm{mM} ; 5-2.92 \mathrm{mM} \mathrm{GdCl}{ }_{3} . \mathrm{C}_{\mathrm{DNA}}=10 \mu \mathrm{g} / \mathrm{ml}$; $\mathrm{C}_{\mathrm{PEG}}=170 \mathrm{mg} / \mathrm{ml} ; \quad \mathrm{C}_{\mathrm{NaCl}}=0.3 \mathrm{M} . \quad \Delta \mathrm{A}=\left(\mathrm{A}_{\mathrm{L}}-\mathrm{A}_{\mathrm{R}}\right) \times 10^{-6}$ optical units, $\mathrm{L}=1 \mathrm{~cm}$.

Inset: The dependence of the amplitude of the abnormal negative band in the CD spectra $(\lambda=270 \mathrm{~nm})$ of the CLCD formed by $\left(\right.$ DNA-Gd ${ }^{3+}$ ) complexes upon $r_{t}$ value. $r_{t}$ is the ratio of the total $\mathrm{CdCl}_{3}$ molar concentration to the molar concentration of the DNA bases. $\mathrm{C}_{\mathrm{DNA}}=10 \mu \mathrm{g} / \mathrm{ml} ; \quad \mathrm{C}_{\mathrm{PEG}}=170 \mathrm{mg} / \mathrm{ml} ; \quad \mathrm{C}_{\mathrm{NaCl}}=0.3 \mathrm{M}$. $\Delta \mathrm{A}_{270} \times 10^{-6}$ optical units; $\mathrm{L}=1 \mathrm{~cm}$

Ds DNA molecules, whose phosphate groups form complexes with $\mathrm{Gd}^{3+}$ ions, lose their solubility. Hence, the DNA molecules are salted-out into CLCD particles. It means that the treatment of the ds DNA CLCD by $\mathrm{GdCl}_{3}$ is accompanied not only by neutralization of phosphate groups of the DNA molecules by $\mathrm{Gd}^{3+}$ ions, but by a significant attraction between the neighboring DNA molecules. Disappearance of the fluidity of the ds DNA CLCD particles proves a short-range attractive interaction between the charged DNA molecules arising from interlocking $\mathrm{Gd}^{3+}$ ions, sometimes called as "counterion crosslinks".
The disappearance of the "fluidity" of DNA molecules and the enhancement of interaction between neighboring DNA molecules in quasinematic layers results in the formation of an integrated structure. The very high-molecular mass of such structure and its insolubility makes this system incompatible with the PEG-containing solution. Hence, "liquid" DNA CLCD particles are transformed into "rigid" (gel-like) constructions ("rigid" particles) [20].

The disappearance of the "fluidity" of DNA molecules and the enhancement of interaction between neighboring DNA molecules in quasinematic layers results in the formation of an integrated structure. The very high-molecular mass of such structure and its insolubility makes this system incompatible with the PEG-containing solution. Hence, "liquid" DNA CLCD particles are transformed into "rigid" (gel-like) constructions ("rigid" particles) [19].

This fact is confirmed by immobilization of rigid particles on the nuclear membrane filter surface . Fig. $7(A$ and $B$ ) shows the images of ds DNA CLCD particles after their treatment with $\mathrm{GdCl}_{3}$ and immobilization on nuclear membrane filter obtained by atomic force microscopy (AFM).

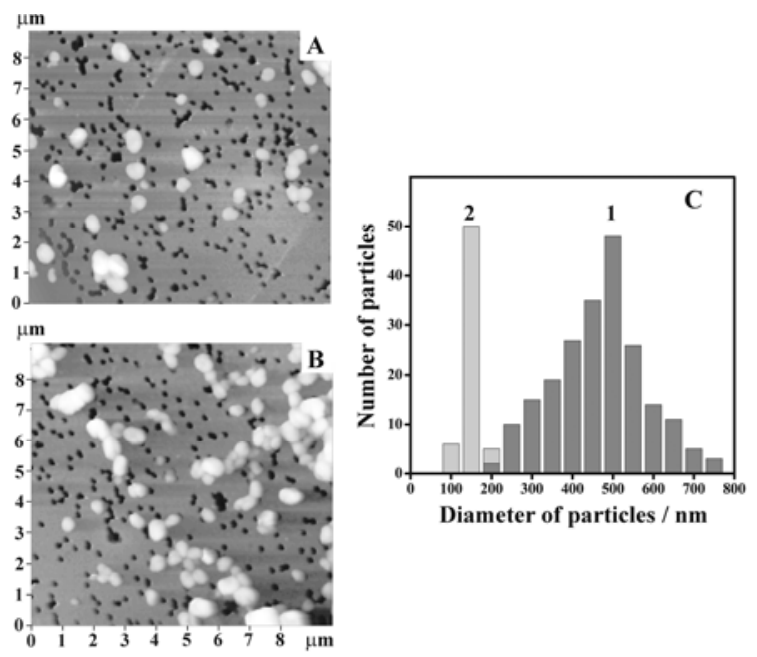

Fig. 7. Left panel: AFM images of the particles of CLCD formed by (DNA- $\mathrm{Gd}^{3+}$ ) complexes and immobilized onto the surface of the nuclear membrane filter (PETP). The dark spots are pores in the nuclear membrane filter. Two sites on the PETP filter are shown (A and B).

Right panel: Size distribution of the ds DNA CLCD particles treated by $\mathrm{GdCl}_{3}$ (1) and the pores (2) in the membrane filter.

$\mathrm{C}_{\mathrm{DNA}}=1.07 \mu \mathrm{g} / \mathrm{ml} ; \mathrm{C}_{\mathrm{PEG}}=17 \mathrm{mg} / \mathrm{ml} ; \mathrm{C}_{\mathrm{NaCl}}=0.3 \mathrm{M}$; $\mathrm{C}_{\mathrm{GdCl} 3}=0.23 \mathrm{mM}[3]$ 
The presence of single individual particles (Fig. 7, $A$ and $B$ ) testifies that the "liquid" character of the DNA packing in these particles is disappeared and each particle has a "rigid" spatial structure. Fig. 7, $C$ demonstrates the size distribution of these particles as well as the pores in the filter. The average size of particles is within $450-500 \mathrm{~nm}$, i.e. this size of the ds DNA CLCD particles after gadolinium treatment coincides with the mean diameter of initial ds DNA CLCD particles [3]. The particles have shape of the spherocylinders and the diameter of particles is close to their height.

An existence of independent particles speaks in favor of an appearance of noncompensated positive surface charge on the CLCD particles. This, in turn, prohibits a quick coalescence of these particles. ((One can note that the precipitation of these rigid particles (process demanding time) results in formation of a pellet. However, its easy stirring with supernatant is accompanied by full restoration of abnormal optical properties of these particles (Fig. 6, curve 5)).

Because each phosphate group of the DNA molecules, carrying one "effective" negative charge, is neutralized by $\mathrm{Gd}^{3+}$ ion [20], which carries three positive charges, this means that the altered surface charge distribution makes an additional contribution to the chiral interaction between adjacent (ds DNA- $\mathrm{Gd}^{3+}$ ) complexes in the particles [21,22]. In this case one can expect that the pitch of the spatial twist of cholesteric structure formed by the ds DNA is changed as a result of interaction of $\mathrm{Gd}^{3+}$ ions with these molecules [17].

Therefore, particles of the CLCD of the ds DNAs whose phosphate groups are neutralized by $\mathrm{Gd}^{3+}$ ions become poorly soluble and can exist in the absence of osmotic pressure of the PEG-containing solution. The osmotic pressure of the aqueous salt PEG-containing solution is not required for supporting the spatial structure of CLCD particles formed by (ds DNA-Gd ${ }^{3+}$ ) complexes.

Thus, the first variant enables the design of rigid DNA particles suitable for practical manipulations.

\section{Practical application of "rigid" particles formed by $\left(\mathrm{DNA}-\mathrm{Gd}^{3+}\right)$ complexes}

An application of rigid particles formed by $\left(\right.$ DNA- $\left.\mathrm{Gd}^{3+}\right)$ complexes as gadolinium carriers in the neutron capture therapy was described and experimentally tested in a set of our papers $[4,17,19$, 23-33].

Gadolinium neutron capture therapy (Gd-NCT) utilizes the following nuclear capture reaction of ${ }^{157} \mathrm{Gd}$ by thermal neutron irradiation [34]:

${ }^{157} \mathrm{Gd}+n$th $\rightarrow{ }^{158} \mathrm{Gd}+\gamma$-rays + internal conversion electrons $\rightarrow{ }^{158} \mathrm{Gd}+\gamma$-rays + Auger electrons + characteristic X-rays (Fig. 8).

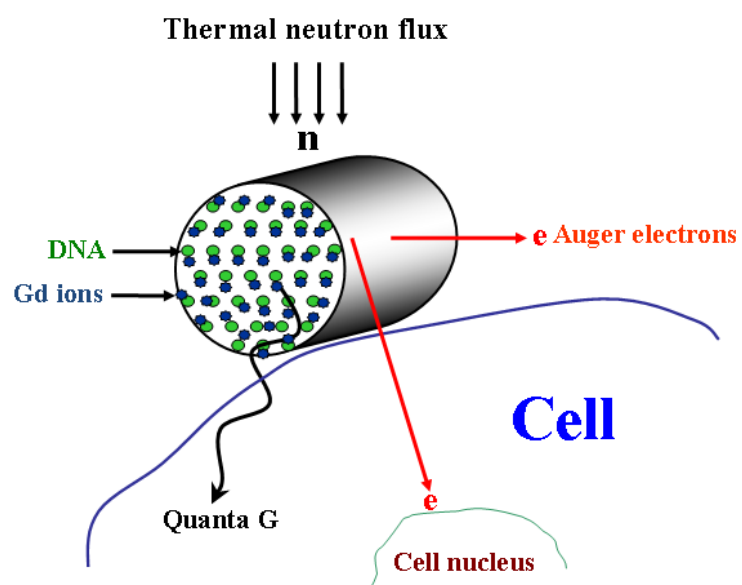

Fig. 8. Schematic representation of the radiation processes caused by the neutron capture in the DNA CLCD particle containing gadolinium ions

According to the accepted point of view, the success of Gd-NCT therapy depends, first, on a high accumulation of $\mathrm{Gd}^{3+}$ in the tumor [35].

A potential of the rigid (ds DNA- $\mathrm{Gd}^{3+}$ ) particles as biomaterial for Gd-NCT, is based on a few facts:

1. the formation of these particles can be easily checked by the CD spectroscopy or by the AFM;

2. a long-term stability of the physicochemical properties of these particles allows one to manipulate with these particles;

3. this biomaterial has a higher concentration of ${ }^{157} \mathrm{Gd}$ (the local concentration of $\mathrm{Gd}^{3+}$ in these structures may reach $40 \%$ ) compared to other known Gd-carriers such as, for instance, Gd-chelate complexes [35-38].

It was shown [19] that that the irradiation of Chinese hamster ovary (CHO) adherent cells (Fig. 9) by the thermal neutron fluence $\left(5 \times 10^{11}\right.$ neutron $\left./ \mathrm{cm}^{2}\right)$ within $1 \mathrm{~h}$ results only in minor (if any!) changes in the $\mathrm{CHO}$ cells and does not influence their ability to grow. However, the irradiation of $\mathrm{CHO}$ cells in presence of rigid particles results in full absence of a live $\mathrm{CHO}$ cells. 


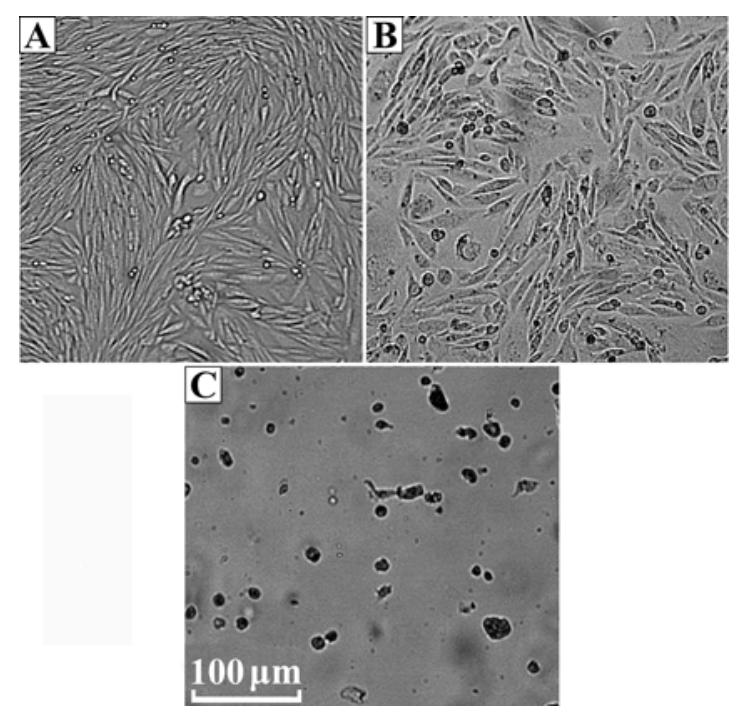

Fig. 9. The images of $\mathrm{CHO}$ cells monolayers taken after 120 hours of cell processing by light microscope (Leica DMI4000):

A - The image without the thermal neutron irradiation and without gadolinium carrier. B - The image with thermal neutron irradiation without gadolinium carrier. $\mathrm{C}$ - The image after $30 \mathrm{~min}$ of the thermal neutron irradiation with gadolinium carrier. Scale bar $=100 \mu \mathrm{m}$

The presence of strongly deformed cells (collapsed cells) allows one to suppose, that although concrete reasons for an appearance of these cells were not investigated carefully, that irradiation of $\mathrm{CHO}$ cells in presence of (ds DNA-Gd $\left.{ }^{3+}\right)$ rigid particles is accompanied by a few processes:

1. disintegration of genetic material of these cells;

2. deformation and destruction of lipoprotein membrane as a result of possible retention of $\mathrm{Gd}^{3+}$-containing particles in lipoprotein membrane of CHO cells;

3. penetration of small fraction of (ds DNA$\mathrm{Gd}^{3+}$ ) rigid particles into the $\mathrm{CHO}$ cells inducing additional destruction of these cells.

In conclusion, one can say that the obtained results $[24,25,30]$ showed that rigid (ds DNA-Gd $\left.{ }^{3+}\right)$ particles have a potential as a novel nanobiomaterial with high concentration of gadolinium for NCT.

\section{Cross-linking of neighboring DNA molecules inside CLCD particles}

Based on the general considerations of polymer physics, we can assume that there is the second approach (Fig. 5,C) for the transformation of a dispersion particle from the liquid to the rigid state.
The basic idea of this approach can be formulated in the following way:

The neighboring ds DNA molecules with phosphate groups neutralized by sodium cations are resided in quasinematic layers of CLCD particles in the "dissolved" state, and there is free space between them. The molecules of chemical substances ("guests") entering the free space due to diffusion can form chemical cross-links between DNA molecules in neighboring quasinematic layers of CLCD particles. Such a cross-linking can result in the formation of an integrated (gel-like) structure involving all DNA molecules ordered in the quasinematic layers of $C L C D$ particles. The integrated structure having a very high molecular mass will be incompatible with a PEG-containing solution. This means that the crosslinking of neighboring DNA molecules will lead to the transition of CLCD particles from the liquid to the rigid state.

Again, the use of DNA CLCD particles is practically interesting because it allows one to control the minor changes in the spatial structure of these particles induced by inside and outside factors.

This approach is similar, in fact, to gelation due to the formation of unordered, artificial chemical cross-links between neighboring molecules of polymers. However, in our case, gelation should be realized in such a way that the fixed distance between neighboring ds DNA molecules in quasinematic layers in one CLCD particle does not change, and the spatial helical structure of DNA CLCD particles is preserved. Therefore, we are dealing with a rather specific inside a particle gelation process with nanometer-scale parameters.

From the theoretical point of view, it is obvious that in order to form the cross-links both between neighboring ds DNA molecules in the same quasinematic layer (Fig. 5, $C$ ) and ds DNA molecules in neighboring layers, these molecules should have the reactive groups for cross-links formation. These groups maybe formed by metal ions specifically fixed in a groove (grooves) on the DNA surface or by chemical groups in the content of planar compounds, which form the complexes with ds DNA molecules. Taking into account the steric location of the DNA reactive groups (in particular, the N-7 atoms of purines) in the grooves on the surface of the ds DNA molecules, it is evident that two neighboring ds DNA molecules must be sterically "phased" to realize the cross-linking of the same reactive groups) [39]. 
Taking into account that the distance between ds DNA molecules in the CLCD particles (2.5$5.0 \mathrm{~nm}$ ), depending on osmotic pressure of a solution) the chemical cross-links have been named as "nanobridges" [40].

One can define a few requirements to the properties of nanobridges which should be created between ds DNA molecules. The nanobridges should:

1. to have the extended spatial structure remaining flat on distance of $2.5-5.0 \mathrm{~nm}$;

2. to be formed from water-soluble substances;

3. to be formed in a aqueous polymeric solution of high ionic strength;

4. to be stable under conditions of low ionic strength of solution.

The compounds chosen as building blocks for nanobridges should:

5. to be chemically or biologically significant;

6. to have an absorption band in visible region of a spectrum;

7. to settle down perpendicularly long axis of DNA molecule. In this case one can expect an appearance of an additional abnormal band in the CD spectrum located in absorption region of the nanobridge chromophores [13, 14].

Besides, at creation of nanobridges between neighboring ds DNA molecules:

8. the mutual ordered arrangement of DNA molecules in CLCD particle should not be broken;

9. the general spatial structure of CLCD particle should remain constant;

10. the forming integrated structure, which includes all ds DNA molecules and nanobridges, should exist in solutions with low osmotic pressure.

All these points mean that the formation of cross-links (nanobridges) between ds DNA molecules ordered in CLCD particle is a delicate process that requires a number of conditions.

The detailed analysis of the properties of compounds that can be used as components for extended nanobridge formation made it possible to choose the molecules of the anthraquinone (anthracycline) group (Fig. 10).

On the one hand, anthracylines contain the chemical groups with high reactivity (ketone oxygen, peri $\mathrm{OH}$ groups, Fig. 10, II) [41]. These compounds, owing to their chemical structure, can form chelate complexes with bi- and trivalent metals ions [41-44]. The chelation process may result in formation of flat polymeric bridge involving a few anthracycline molecules (Fig. 10, IV) linked by bivalent metal ions [39].

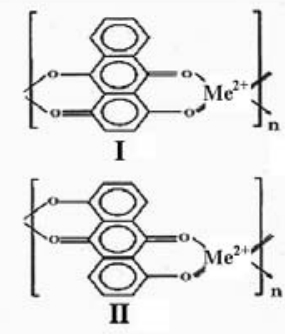

Structure of anthracycline drugs
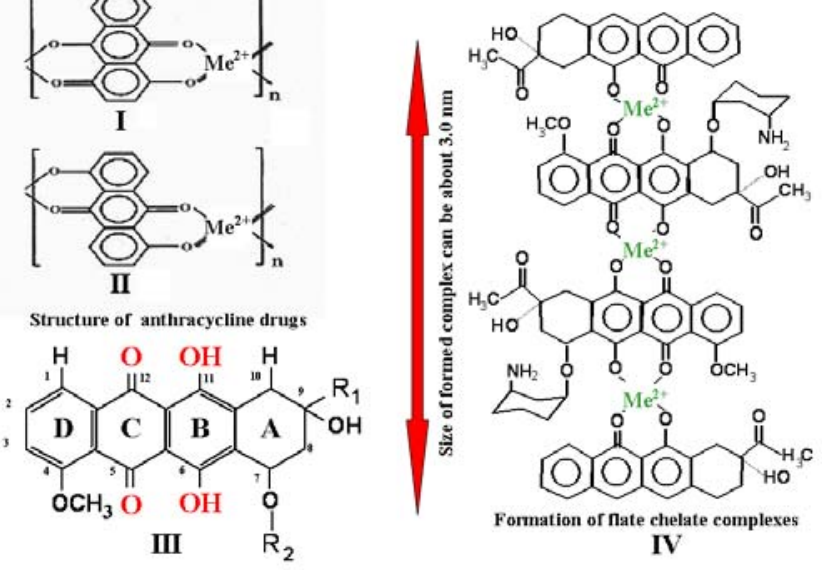

Water-soluble compounds (size is $0.3-0.5 \mathrm{~nm}$ )

Fig. 10. Examples of chelate complexes of bivalent cations with flate aromatic compounds

Analysis of the various anthracyclines that differ by the presence and the location of aglycone substituents has shown that one of the basic prerequisite for the formation of extended flat complexes is the presence of reactive oxygen atoms at the positions 5, 6 and 11, 12 (or 1,2) of anthracycline aglycone (Fig. 10, III) [45].

The chelate complexes with bivalent copper ions attract special interest because of the specific electron structure of a bivalent copper ion [46]. The chelate complexes with copper ions may contain up to 10 (ten) repeating subunits; that is, under certain conditions, they can form extended spatial planar (flat) structure $[43,47]$. This means that the water-soluble antibiotics of the anthracycline group form flat, rigid, chelate complexes with metal ions.

On the other hand, the anthracyclines can interact with ds DNA molecules by different modes [48-50]. These compounds, in particular, daunomycin (DAU) can intercalate between the bases pairs of DNA or synthetic polynucleotides of B-family only. The reactive groups of DAU become unavailable for chemical reactions upon intercalation. However, DAU and its analogs can form so-called "external" complexes with nucleic acids of B- and A-families. In this case, DAU molecules may be disposed in proximity to DNA molecule surface and the reactive groups of DAU prove to be available for chemic reactions, for instance, for chelate formation. 
Hence, the problem is reduced to the formation of chemical cross-links (nanobridges) with adjustable properties between neighboring ds DNA molecules fixed (due to constant osmotic pressure of the used PEG-containing solution, $\mathrm{C}_{\mathrm{PEG}}=170 \mathrm{mg} / \mathrm{ml}$ ) at an interhelical distances about $3.5 \mathrm{~nm}$ in quasinematic layers in structure of CLCD particles without significant change in the total spatial organization of CLCD particles.

The details of the technology of treatment of DNA CLCD with DAU and a copper salt are thoroughly described in the literature [45, 48, 51-53].

Formation of nanobridges was realized according to scheme shown in Fig. 11.The DNA CLCD was obtained by mixing equal volumes of water-salt DNA and PEG solutions (Fig. 11, curve 1).

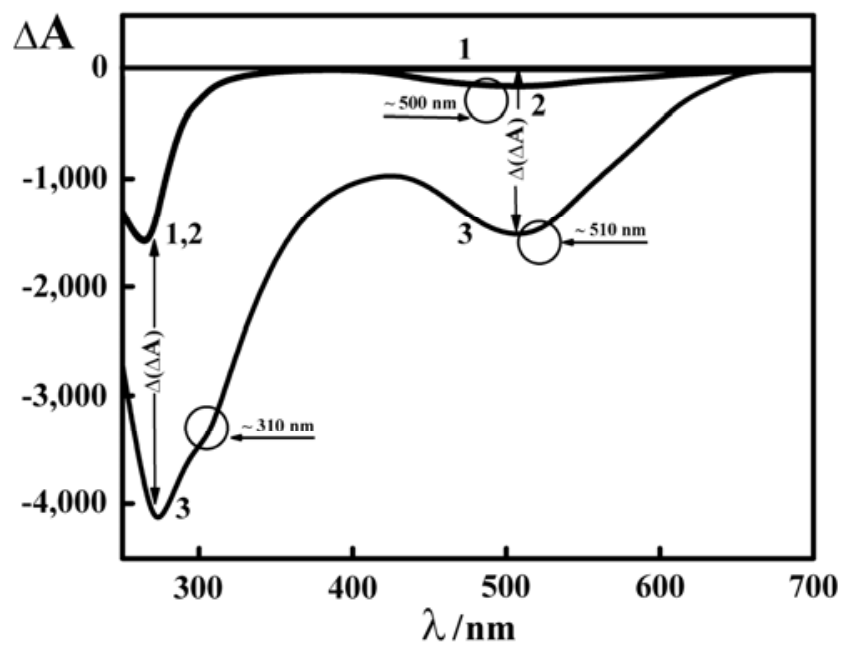

Fig. 11. The CD spectra of DNA CLCD (curve 1) and CLCD of DNA successively processed by DAU (curve 2) and $\mathrm{CuCl}_{2}$ (curve 3 ) solutions [18]:

$\mathrm{C}_{\mathrm{DNA}} \sim 5.5 \mu \mathrm{g} / \mathrm{ml} ; \quad \mathrm{C}_{\mathrm{PEG}}=170 \mathrm{mg} / \mathrm{ml} ; \quad 0.3 \mathrm{M} \mathrm{NaCl}+0.002 \mathrm{M}$ $\mathrm{Na}^{+}$-phosphate buffer; $\mathrm{C}_{\mathrm{DAU}}=27.3 \times 10^{-6} \mathrm{M} ; \mathrm{C}_{\mathrm{Cu} 2+}=9.9 \times 10^{-6} \mathrm{M}$. $\Delta \mathrm{A}=\left(\mathrm{A}_{\mathrm{L}}-\mathrm{A}_{\mathrm{R}}\right) \times 10^{-6}$ optical units, $\mathrm{L}=1 \mathrm{~cm} . \Delta(\Delta \mathrm{A})$ is the extraamplification of the abnormal band in the CD spectrum

Fixed volumes of DAU solution were subsequently added to the DNA CLCD (Fig. 11, curve 2). The amplitude of the intense negative band at $\lambda \sim 270 \mathrm{~nm}$ indicates the left-handed twist of the spatial structure of CLCD. It remains practically unchanged at any reasonable DAU concentration added to the CLCD. An addition of DAU to the DNA CLCD is accompanied by an appearance of a new band located in the absorption region of DAU chromophores $(\lambda \sim 500 \mathrm{~nm})$. The amplitude of this band grows with increasing DAU concentration, reaching an equilibrium value at the DAU concentration that corresponds to the maximal extent of the DNA saturation by DAU molecules and does not change upon further growth of DAU concentration. The negative sign of the band at $\lambda \sim 500 \mathrm{~nm}$ reflects an intercalation of DAU molecules between the nitrogen base pairs of DNA molecules, fixed at a particular distance due to the osmotic pressure of a PEG solution.

The addition of $\mathrm{CuCl}_{2}$ solution to the DNA CLCD treated by DAU (Fig. 11, curve 3 ). with an equilibrium band amplitude at $\lambda \sim 500 \mathrm{~nm}$ results in an amplification of both this band and the band located in the UV region of the spectrum.

It should be noted that no substantial alterations in the CD spectrum in the DAU absorption region were observed when CLCD composed of ds RNA molecules (A-family) were treated with DAU. The lack of a strong CD band in the region of DAU absorption indicates that no intercalation complex is formed between DAU and RNA. The treatment of CLCD formed by RNA or ds poly $(\mathrm{A}) \times \operatorname{poly}(\mathrm{U})$ and triple-stranded polyribonucleotide poly $(\mathrm{A}) \times 2$ poly $(\mathrm{U})$ molecules (all belong to A-family), where intercalation of DAU is not possible at all, by DAU and $\mathrm{Cu}^{2+}$ ions is accompanied by changes in their CD spectra which are similar to shown above for ds DNA case (Fig. 11, curve 3).

It was marked above that the "external" complexes formed by DAU molecules are acceptable for chemical reaction, for instance, for formation of a chelate complex with $\mathrm{Cu}^{2+}$ ions. Because amplification of the optical properties of isotropically located chromophores is impossible, the results shown in Fig. 11 (curve 3) suggest that the (DAU- $\mathrm{Cu}^{2+}$ ) chelate complexes should be specifically ordered near the surface of nucleic acid molecules in the content of the particles of CLCDs. The direction of the long axis of the bridges, formed by (DAU- $\mathrm{Cu}^{2+}$ ) complexes, is perpendicular to the direction of the long axis of the nucleic acid molecules.

Thus, the reason for the increase in the amplitude of band in the CD spectrum of CLCD of ds DNA successively treated by $\mathrm{DAU}$ and $\mathrm{CuCl}_{2}$ is the formation of cross-links (nanobridges) between neighboring DNA molecules.

One can add that the theory [13] predicts that when the chelate complexes (nanobridges) between ds DNA molecules in quasinematic layers are specifically oriented in respect to the long axes of ds DNA molecules, one can expect an appearance of an intense 
band in the CD spectrum located in absorption region of the DAU chromophores (Fig. 11). The direction of the long axis of the bridges, formed by $\left(\mathrm{DAU}-\mathrm{Cu}^{2+}\right)$ complexes, proves to be perpendicular to the direction of the long axis of the nucleic acid molecules, although the orientation of DAU molecules is close to that of the nitrogen base pairs.

It was shown that multiple dilutions of PEGcontaining aqueous salt solution do not lead to an appreciable decrease in the specific abnormal optical activity of the DNA CLCD treated by DAU and $\mathrm{CuCl}_{2}$, meaning that the mutual orientation of neighboring DNA molecules is not violated even outside the "boundary" conditions (Fig. 4, B). It means that the osmotic pressure of solution is not the main factor affecting the character of packing DNA molecules in a CLCD particle. Hence, neighboring ds DNA molecules are indeed cross-linked, and crosslinks stabilize the spatial structure of the CLCD particles.

Thus, the reason for the increase in the amplitude of band in the CD spectrum of CLCD of ds DNA successively treated by DAU and $\mathrm{CuCl}_{2}$ is the formation of cross-links (nanobridges) between neighboring DNA molecules.

The efficiency of the formation of nanobridges depends on concentrations of both DAU molecules and copper $[53,54]$. Due to the presence of the nanobridges between neighboring DNA molecules, the spatial structure of CLCD particles remains stable for a long time (months) at PEG and $\mathrm{NaCl}$ concentrations significantly below those at which the CLCD particles, not stabilized with nanobridges, can exist [55].

Consequently, the created structure can exist not only in solutions with low ionic strength, but also in solutions with a very low (up to zero) concentration of PEG, i.e., under the conditions of a low osmotic pressure of the solution.

The theoretical evaluations $[39,51,56-59]$ showed that one nanobridge can include from four to six ions. The direct magnetometric estimation of $\mathrm{Cu}^{2+}$ cations [60] in the content of ds DNA CLCD particles demonstrated that one nanobridge between ds DNA molecules fixed in the content of CLCD particles formed at $\mathrm{C}_{\mathrm{PEG}}=170 \mathrm{mg} / \mathrm{ml}$ can contain from four to six copper ions. (The calculation of the number of $\mathrm{Cu}^{2+}$ ions in the content of the nanobridges is based on the measurement of the magnetic susceptibility (magnetic moment) of a $\mathrm{Cu}^{2+}$ ion being in the $d^{9}$ state with four reactive oxygen atoms at the nanobridge formation [46]).

Consequently, the experimental data and the results of theoretical calculations allow one to accept that a nanobridge $\left[\ldots-\mathrm{Cu}^{2+}\right.$-DAU- $\mathrm{Cu}^{2+} \ldots \mathrm{Cu}^{2++}$-DAU$\left.\mathrm{Cu}^{2+} \ldots\right]$ contains six ions of bivalent copper. Nanobridges are flat chelate complexes. (See the structures in Fig. 12, where panel A depicts a nanobridge (view along the DNA molecule axis) and panels $\mathbf{B}$ and $\mathbf{C}$ show a more detailed structure of nanobridges between ds DNA molecules that link DNA molecules located both in one layer and in adjacent layers. For the sake of simplicity, the nanobridges are turned $90^{\circ}$ relative to their actual orientation). The stabilization of the polymeric chelate complex is reached here by "bridging" the chelate system [DNA-DAU- $\left(\mathrm{Cu}^{2+} \text {-DAU.......DAU- } \mathrm{Cu}^{2+}\right)_{\mathrm{n}}$ DAU-DNA] between two neighboring DNA molecules, whose mutual orientation is fixed in the structure of CLCD particle.

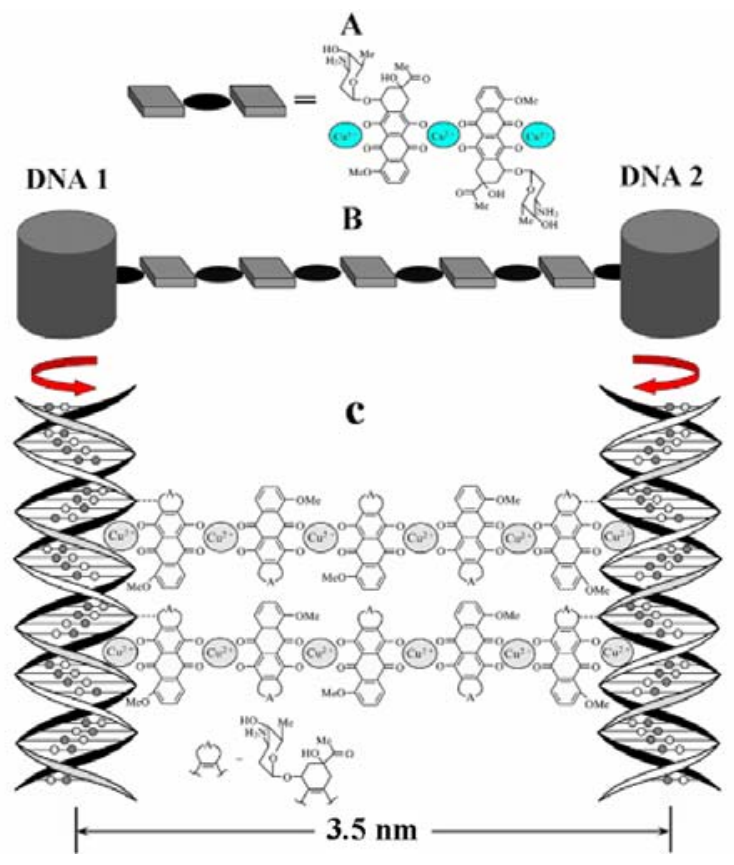

Fig. 12. The structure of nanobridges formed between two adjacent DNA molecules fixed in the spatial structure of CLCD particles [18]:

A - Structure of chelate complex between DAU molecules and copper ions, B - Shematic top view of nanobridges between two DNA molecules, $\mathbf{C}-$ Side view of nanobridges between DNA-1 and DNA-2 molecules (for simplicity, nanobridges are turned $90^{\circ}$ with reference to their standard position) 
The emergence of chemical cross-links (nanobridges) between neighboring DNA molecules results in the formation of three dimensional, highmolecular mass, integrated structure which includes all ds DNA molecules. This structure is incompatible with PEG-containing solution. The stability of this structure is determined by the number and properties of nanobridges rather than the properties of the initial PEG-containing solution [61].

The AFM images of rigid particles are shown in Fig. 13, $A, B$. Examination of the size distribution of 113 particles showed that the particles have a shape reminiscent of a prolate cylinder, and although their sizes vary from 300 to $700 \mathrm{~nm}$, they have an average diameter of about $500 \mathrm{~nm}$ (Fig. 13, C). Consequently, the size of the formed CLCD particles with ds DNA cross-linked with nanobridges coincides with the size of the initial DNA CLCD particles calculated theoretically for the case of solutions with the constant osmotic pressure (see above).

A
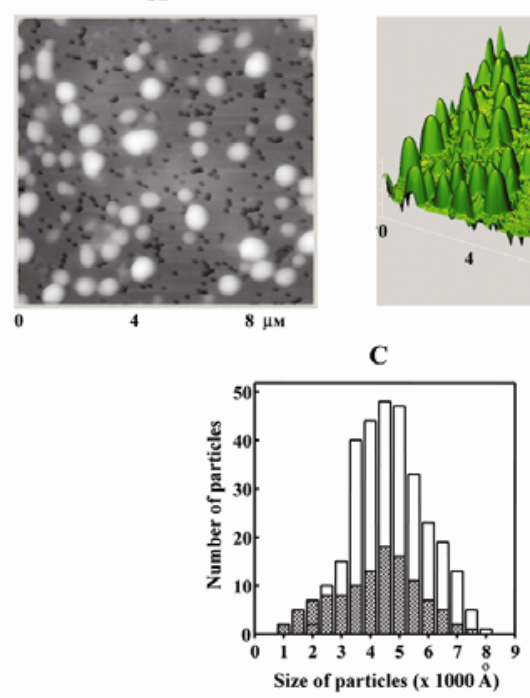

Fig. 13. 2-D (A) and 3-D (B) images of CLCD particles with DNA molecules cross-linked with nanobridges and their size distribution (C) [3]

The AMF results allow one to estimate several parameters of rigid DNA particles [4]. It was shown that one rigid DNA particle contains approximately
$1.6 \times 10^{4}$ DNA molecules and the molecular mass of one rigid particle amounts to $(1.0-1.2) \times 10^{10} \mathrm{Da}$, i.e., it is close enough to the molecular mass of initial DNA CLCD particles formed in the course of the phase exclusion.

The unique spatial structure of bridged DNA CLCD particles, the variety of the building blocks (DNA molecules, copper ions, anthracycline molecules) and the dependence of their properties on a number of factors (temperature, concentration of the polymer, and copper and anthracycline concentration) make it possible to manipulate the properties of this structure.

Thus, the second variant of gelation allows one to transform "liquid" DNA CLCD particles to rigid state and allows one to prepare rigid DNA particles that can be also suitable for manipulations.

Note that the both scenarios considered above cover, in fact, all the approaches for producing rigid DNA particles that are possible in the framework of the physical chemistry of polymers.

\section{Practical application of "rigid" particles formed by cross-linking of DNA molecules with nanobridges}

Rigid particles can be used as carriers of biologically active compounds (BACs) in the content of nanobridges in medicine and biosensorics. An application of rigid particles was as biosensing units for detection on a few compounds of practical importance was described and experimentally tested in a set of our papers [62].

The main idea of sensing BAC based on the following facts. It is known that action of BACs ("guests") on nanobridges between ds DNA molecules ordered in quasinematic layers of CLCD particles formed in PEG-containing solutions results in two processes: i) disintegration of structure of bridges accompanied by disappearance on abnormal negative band in the visible region of the $\mathrm{CD}$ spectrum and ii) conservation of initial structure of DNA CLCD in solutions of certain PEG-osmotic pressure. These facts allow one to detect concentration of "guests" under various conditions (Fig. 14). 


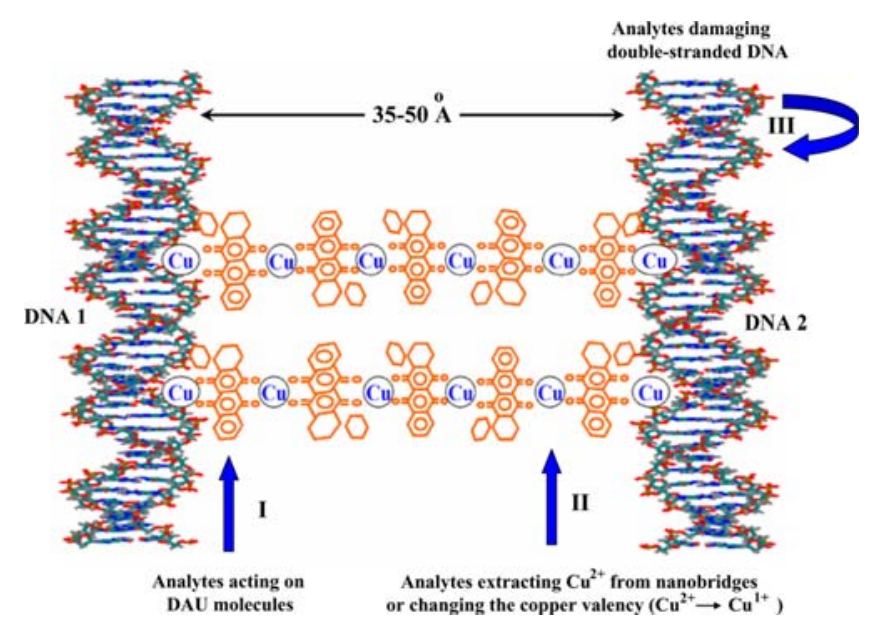

Fig. 14. A rigid DNA particle as an integral sensing element (bosensng unit):

I - III - substances to be analyzed

For instance, recently [63] such biosensing units have been used for determination of heparin concentration (Fig. 15) and easily discrimination between heparin samples having different molecular masses.
Besides, one can immobilize the rigid particles formed by cross-linking of DNA molecules with nanobridges in the content of transparent polymeric film and use this object as a biosensing unit with longterm stability [64].

Hence, the physicochemical approach based on gelation of the adjacent ds DNA molecules inside the CLCD particles allows one to obtain rigid DNA particles of practical importance.

\section{Formation of "rigid" spatial structures from DNA liquid-crystalline dispersion particles: Nanotechnological approach}

The development of nanotechnologies opened up the possibility for a new way to form rigid ds DNA particles. Here, a few remarks are necessary for the beginning.

1. In a few reviews [65-68] has been shown that nanoparticles (NPs) of different origin not only are compatible with LC phases of low molecular compounds but, under certain conditions, can induce the formation of new LC materials having novel properties [69].
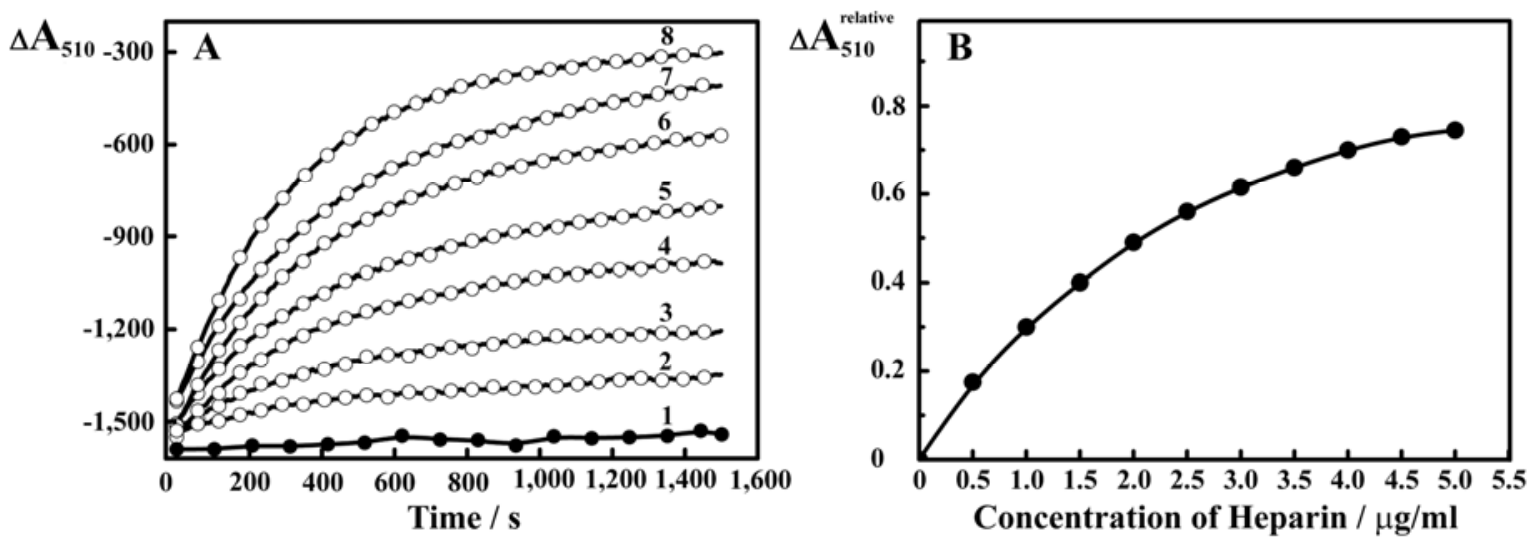

Fig. 15. Kinetics of degradation of the biosensing unit based on DNA rigid particles under heparin action (A) and its analytical sensitivity to heparin (B):

A - Kinetic curves characterizing the change in the amplitude of the band in the CD spectrum $(\lambda=510 \mathrm{~nm})$ of the biosensing unit versus the time treatment with heparin:

$\mathrm{C}_{\text {Heparin }}(\mu \mathrm{g} / \mathrm{ml}): 1-0 ; 2-0.25 ; 3-0.5 ; 4-1.0 ; 5-1.5 ; 6-2 . ; 7-3.0 ; 8-4.0 . \Delta \mathrm{A}_{510^{\circ}} \times 10^{-6}$ optical units; $\mathrm{L}=1 \mathrm{~cm}$

B - The calibration curve for determination of the heparin concentration using biosensing unit based on DNA rigid particles. (Processing time of the biosensing unit treatment with heparin $-10 \mathrm{~min}$.):

$\Delta \mathrm{A}_{510}{ }^{\text {relative }}=\left(\Delta \mathrm{A}_{510}{ }^{\text {initial }}-\Delta \mathrm{A}_{510}{ }^{\text {mesured }}\right) / \Delta \mathrm{A}_{510}{ }^{\text {initial }}$, where: $\Delta \mathrm{A}_{510}{ }^{\text {initial }}$ и $\Delta \mathrm{A}_{510}{ }^{\text {mesured }}$ - the amplitude of the band in the CD spectrum of the biosensing unit at $\lambda=510 \mathrm{~nm}$ before and after addition of heparin.

$\mathrm{C}_{\mathrm{DNA}}=5.5 \mu \mathrm{g} / \mathrm{ml} ; \mathrm{C}_{\mathrm{PEG}}=170 \mathrm{mg} / \mathrm{ml} ; 0.3 \mathrm{M} \mathrm{NaCl}+0.002 \mathrm{M} \mathrm{Na}^{+}$- phosphate buffer; $\mathrm{C}_{\mathrm{DAU}}=30.0 \times 10^{-6} \mathrm{M} ; \mathrm{C}_{\mathrm{CuCl} 2}=4.0 \times 10^{-6} \mathrm{M}$.

The 6th International Standard of Unfractionated Heparin (NIBSC code: 07/328), provided by the Laboratory for Biological Standards of the WHO (National Institute for Biological Standards and Control, UK) was used to prepare the calibration solution 
2. From the point of view of nanotechnology, gold nanoparticles (AuNPs) attract the greatest interest $[70,71]$.

Gold $(\mathrm{Au})$ is the element with the electron configuration $5 d^{10} 6 s^{I}$. The gold atom contains one selectron in the outer shell; the next shell, comprising ten $d$-electrons, is unstable. The chemical properties of gold are defined by light activation of $5 d$-electrons and by the tendency to acquire an additional electron to complete the $6 s^{2}$-level and "prevent" the loss of the existing electron [65].

Following [72, 73] we assume that a AuNps with diameter $\sim 2 \mathrm{~nm}$ consists of 150 atoms. (There is a perception [74] that a AuNP with diameter of $2.3 \mathrm{~nm}$ represents an octahedron and consists of 300 atoms (Fig. 16)). A rough estimate shows that in the case of a $2 \mathrm{~nm}$ particle size, about $60 \%$ of the atoms are surface atoms with uncompensated valence [75]. Hence, valence electrons become more accessible for binding of ligands $[76,77]$.

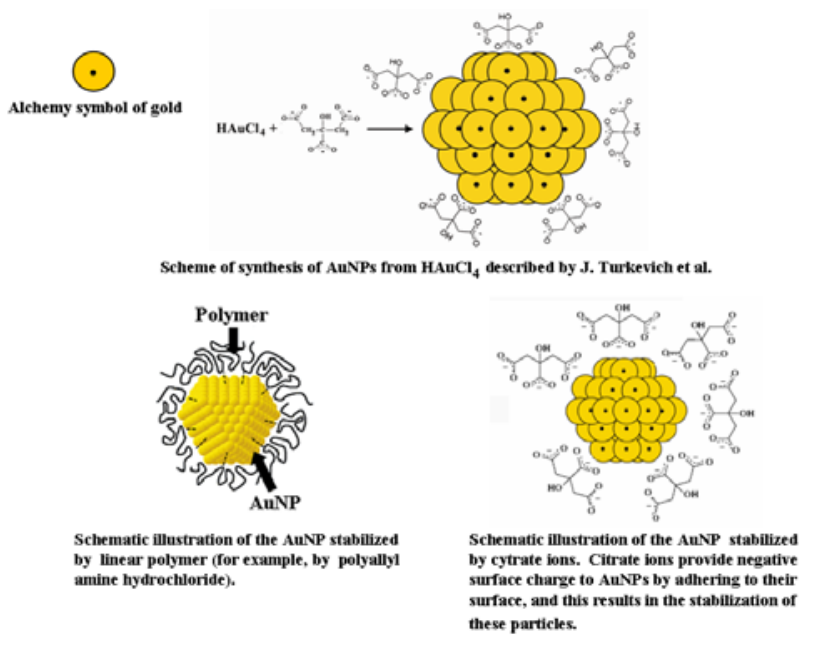

Fig. 16. Formation and properties of gold nanoparticles

The presence of surface layers of $\mathrm{Au}(100)$ and $\mathrm{Au}$ (111) in the spatial structure of the AuNPs determines the difference in their polarity [78] the efficiency of the dipole-dipole interaction between adjacent AuNPs, the efficiency of self-assembly AuNPs of different forms, and the efficiency of ligand binding. It means that small-size AuNPs have a high propensity to interact with different substances.

It is important that the monodentate ligands weakly bound to the surface of the AuNPs may be replaced by polydentate ligands $[65,79-83]$.
Gold nanoparticle can also change form as a "jelly," undergoing structural deformation depending on the type of substrate on the surface [75].

3. Study of the interaction between AuNPs and single-stranded linear DNA molecules was started in the pioneering works by Mirkin and Alivisatos in 1996 [84-89]. These studies have shown that molecules of single-stranded DNA after interaction with the positively charged molecules containing AuNPs can hybridize with complementary single-stranded DNA. In the formed ds hybrids AuNPs are fixed near the surfaces of DNA molecules and the aggregates possess planar structure consisting of alternating ds DNA molecules and AuNPs (... - ds DNA-Au-ds DNA-Au-ds DNA-...).

4. The formation of aggregates from a neighboring AuNP near the surface of the DNA leads to the strengthening of the so-called band of localized surface plasmon resonance (SPR) band) in the visible absorption spectrum $(\lambda \sim 500 \mathrm{~nm})[65,71]$. The SPR band can be shifted to the "red" or "blue" zone depending on a number of parameters (distance between particles, size and shape of formed aggregates, dielectric constant of media, presence of interlayers between adjacent AuNPs, etc.) [73]. Hence, AuNPs have a unique set of chemical and physical properties depending on their size, shape, structure, and dielectric environment, etc.

5. The results obtained by application of the physicochemical approaches showed that ions or molecules of BACs ("guests") can enter the free space in quasinematic layers of ds DNA CLCD particles due to diffusion and transform these molecules into insoluble state.

Points 1-5 permit us formulate the idea of the nanotechnological approach to the formation of rigid DNA particles in the following way:

The neighboring ds DNA molecules with phosphate groups neutralized by sodium cations are resided in quasinematic layers of CLCD particles in the dissolved state, and there is free space between them. Golden nanoparticles comparable in size to the distance between neighboring ds DNA molecules can fill this free space due to diffusion. The fixation of single AuNPs between nearby ds DNA molecules or the formation of extended Au-clusters between them means that the action of AuNPs on ds DNA CLCD particles causes their metallization. Besides, single NPs and especially their clusters are playing the role of a homogeneous medium through which an 
enhancement of the interaction between ds DNA molecules in quasinematic layers occurs. As a result, the physical cross-linking of neighboring metallized ds DNA molecules takes place. Under these conditions, an integrated structure, which includes virtually all the ds DNA molecules of one CLCD particle, is formed. The solubility of metalized integrated(gel-like) structure having a high molecular mass lowers; it becomes incompatible with the PEG-containing solution. The stability of the integrated structure is determined not by the properties of the initial PEGcontaining solution but by the number of single AuNPs and Au-clusters contained in the structure. The rigid (insoluble) metalized structure can exist even in the absence of a high solution osmotic pressure. This means that ds DNA CLCD particles undergo the transformation from the liquid to rigid state.

The CD spectra of CLCDs formed by two types (families) of NAs and treated with AuNPs are displayed in Fig. 17. This Figure needs a few comments.

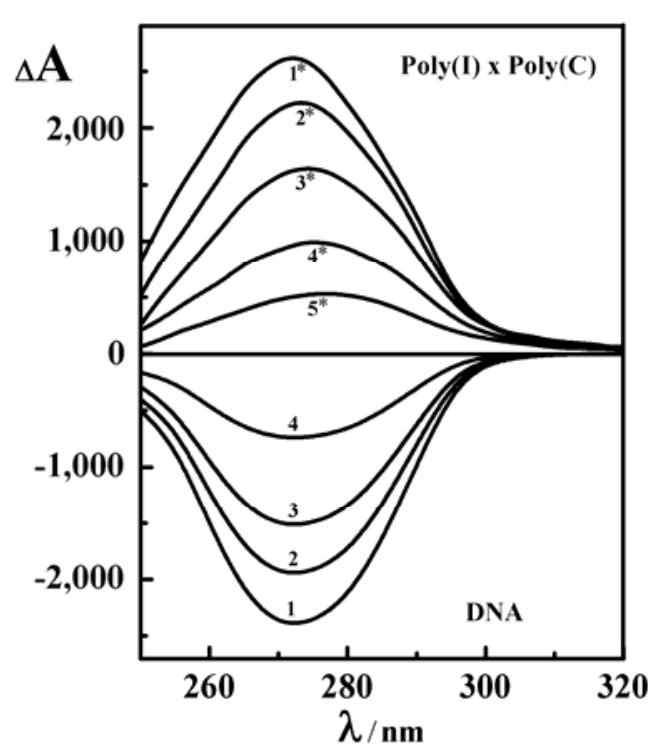

Fig. 17. CD spectra of CLCD of ds DNA (curves 1-4) and CLCD of ds poly $(\mathrm{I}) \times \operatorname{poly}(\mathrm{C})\left(\right.$ curves $\left.1^{*}-5^{*}\right)$ doped with AuNPs $(2 \mathrm{~nm})[54]$ :

$1-\mathrm{C}_{\mathrm{AuNP}}=0 ; 2-\mathrm{C}_{\mathrm{AuNP}}=0.07 \times 10^{14} ; 3-\mathrm{C}_{\mathrm{AuNP}}=0.26 \times 10^{14}$; $4-\mathrm{C}_{\mathrm{AuNP}}=0.82 \times 10^{14}$ particle $/ \mathrm{ml} . \mathrm{C}_{\mathrm{DNA}}=9 \mu \mathrm{g} / \mathrm{ml} ; \mathrm{C}_{\mathrm{PEG}}=$ $150 \mathrm{mg} / \mathrm{ml} ; 0.27 \mathrm{M} \mathrm{NaCl}+1.78 \times 10^{-3} \mathrm{M} \mathrm{Na}^{+}$-phosphate buffer $1^{*}-\mathrm{C}_{\mathrm{AuNP}}=0 ; 2^{*}-\mathrm{C}_{\mathrm{AuNP}}=0.16 \times 10^{14} ; 3^{*}-\mathrm{C}_{\mathrm{AuNP}}=0.33 \times 10^{14}$; $4^{*}-\mathrm{C}_{\mathrm{AuNP}}=0.66 \times 10^{14} ; 5^{*}-\mathrm{C}_{\mathrm{AuNP}}=0.82 \times 10^{14}$ particle $/ \mathrm{ml}$. $\mathrm{C}_{\text {poly( I ) } \times \text { poly ( C ) }}=9 \mu \mathrm{g} / \mathrm{ml} ; \mathrm{C}_{\mathrm{PEG}}=170 \mathrm{mg} / \mathrm{ml} ; 0.27 \mathrm{M} \mathrm{NaCl}+$ $1.78 \times 10^{-3} \mathrm{M} \mathrm{Na}^{+}$-phosphate buffer. $\Delta \mathrm{A}=\left(\mathrm{A}_{\mathrm{L}}-\mathrm{A}_{\mathrm{R}}\right) \times 10^{-6}$ optical units; $1=1 \mathrm{~cm}$
1. One can see that in the CD spectra of $f$ both types of dispersions the abnormal bands are appeared (curve 1 and curve $1^{*}$ ). These bands univocally testify the spatially twist of neighboring quasinematic layers in dispersion particles, hence, cholesteric mode of molecules packing is typical of these dispersions.

The negative abnormal band in the CD spectrum shows that the right-handed ds DNA molecules (B-family) form the CLCD with left-handed spatial twist. The positive abnormal band in the CD spectrum demonstrates that the right-handed ds poly $(\mathrm{I}) \times \operatorname{poly}(\mathrm{C})$ molecules (A-family) form the CLCD with right-handed spatial twist $[3,14,60]$.

2 . One can see that the amplitudes of abnormal bands drastically decreases upon increasing the AuNP concentration in the polymer containing solution (the zeta-potential of AuNPs fall in the range of - (3040) $\mathrm{mV}$, i.e., AuNPs carry a negative charge). In the case of ds DNA CLCD the amplitude of the abnormal band begins to decrease from the "critical" concentration of AuNPs, amounting to approximately 1000 AuNPs per ds DNA CLCD particle.

The higher the concentration of AuNPs in solution, the greater the decrease in abnormal band in CD spectra of CLCDs. (Here a comment is in order. Any possible aggregation of independent AuNPs outside of the CLCD particles cannot induce any change in the $\mathrm{CD}$ spectrum in the region of absorption of nitrogen bases).

3. The observed decrease in the amplitudes of abnormal bands indicates the binding of AuNPs with the ds DNA (or ds poly $(\mathrm{I}) \times \operatorname{poly}(\mathrm{C})$ ) molecules forming the quasinematic layers in the CLCD structure.

4. As noted above, the binding of AuNPs by DNA molecules in the quasinematic layers can cause the layers to tend toward a parallel arrangement. A decrease in the optical activity points to the untwisting of the spatial helical structure of CLCD particles formed of ds DNA (B-family) or poly(I) $\times$ poly (C) (Afamily) molecules, i.e., the nematization of their structures, irrespective of the features of the secondary structure of these molecules.

Hence, doping of ds DNA CLCD (or ds poly(I) $\times$ poly $(\mathrm{C}))$ molecules with AuNPs of small size $(2 \mathrm{~nm})$, carrying a negative charge, demonstrates that these AuNPs can interact with ds nucleic acid molecules in the PEG-containing solution of high ionic strength $(0.3 \mathrm{M} \mathrm{NaCl})$. 
The interaction between negatively charged AuNPs and ds nucleic acid molecules tightly packed in CLCD particles leads to a disturbance of the spatial structure of these particles and causes a decrease in abnormal band in the $\mathrm{CD}$ spectrum. This spectral change can be described as unwinding of the cholesteric spiral, i.e., cholesteric $\rightarrow$ nematic phase transition.

Noticeable changes both in the visible and in the UV spectral regions are observed after DNA CLCD particles have been treated with AuNPs (Fig. 18).

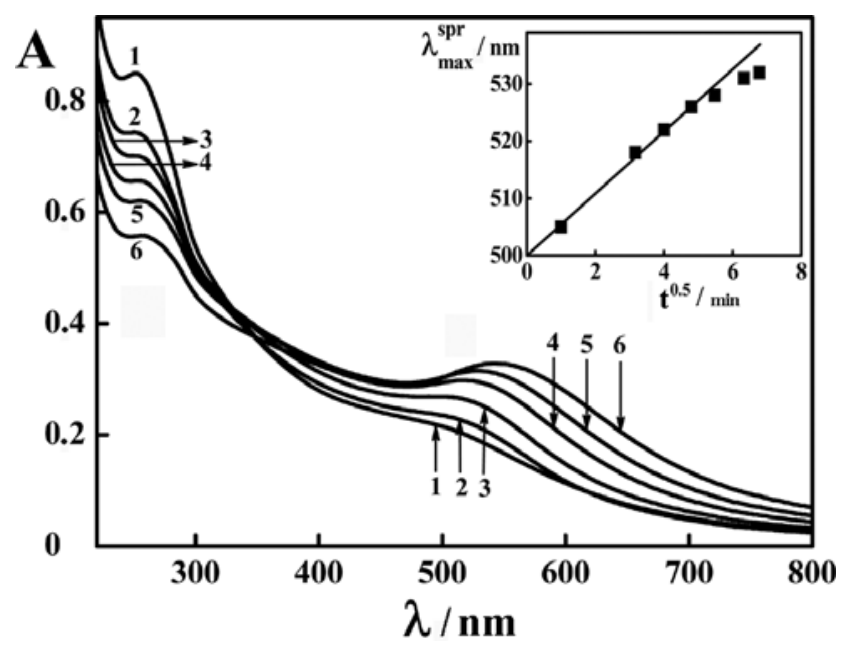

Fig. 18. Development of SPR band in the absorption spectrum of AuNPs added to ds DNA CLCD [18]:

SPR band amplitude was taken at different time: $1-1 \mathrm{~min}$; 2 - $10 \mathrm{~min} ; 3$ - $23 \mathrm{~min} ; 4-46 \min ; 5-148 \mathrm{~min} ; 6-1320 \mathrm{~min}$. $\mathrm{C}_{\mathrm{DNA}}=9.8 \mu \mathrm{g} / \mathrm{ml} ; \mathrm{C}_{\mathrm{PEG}}=150 \mathrm{mg} / \mathrm{ml} ; \mathrm{C}_{\mathrm{AuNP}}=0.17 \times 10^{15}$ particle $/ \mathrm{ml}$; $0.3 \mathrm{M} \mathrm{NaCl}+0.002 \mathrm{M} \mathrm{Na}^{+}$-phosphate buffer.

Inset: Dependence of the location of SPR band maximum in the absorption spectrum of DNA CLCD doped with AuNPs versus time

Fig. 18 shows, as an example, the results obtained at $\mathbf{C}_{\mathrm{PEG}}=166 \mathrm{mg} / \mathrm{ml}$. After the doping of ds DNA CLCD the amplitude of weak band at $\sim 500 \mathrm{~nm}$ (curve 1) increases with time (curves 2-6), and its maximum shifts from $\lambda \sim 500 \mathrm{~nm}$ (curve 1) to $\lambda \sim 530 \mathrm{~nm}$ (curve 6). The emergence of band at $\sim 500 \mathrm{~nm}$ reflects the development of the surface plasmon band typical of AuNPs [65, 71].

The band in the UV spectral range corresponds to the absorption of DNA nitrogen bases. According to the theoretical calculations [84] similar changes in bands located in the UV and visible region of the absorption spectrum correspond to the increase of the volume fraction of AuNPs in ensembles formed by these particles.

The "red" shift of the SPR band is due to the change in AuNPs cluster size [90]. The dependence of the position of the SPR band peak on the size of the linear clusters formed by AuNPs in DNA CLCD particles was obtained in [91-94]. Using results of these papers the size of linear AuNP cluster formed after 148 min should be $\sim 35 \mathrm{~nm}$.

The inset in Fig. 18 shows the dependence of location of maximum of SPR band in the absorption spectrum of DNA CLCD treated with AuNPs versus time. It is important to note, that $\lambda_{\max }{ }^{\text {SPR }}$ (up to the moment of its saturation) is proportional to $t^{1 / 2}$ value.

We can accept that the position of SPR band is connected with the size of AuNPs clusters and the displacement of this band reflects the increase in their size $[65,71]$. The analysis of this process theoretically performed by Lifshitz and Sleozov [95] has shown that the size (R) of the spherical cluster increases proportionally to $t^{1 / 3}$ value. Application of Lifshitz and Slyozov approach to the description of the growth of the cylindrical cluster shows that the length (L) of the cylinder is growing proportionally to $\mathrm{t}^{1 / 2}$ value (independent of the cylinder radius). This theoretical evaluation fits quite well the experimental curve shown in inset in Fig. 18, which illustrates the change in the location of the SPR band in time. This curve means that between ds DNA molecules ordered in dispersion particles, the linear AuNP clusters (ensembles) between neighboring ds DNA molecules in quasinematic layers of CLCD particles linear AuNP are forming [96, 97].

Various versions of fixation of AuNPs (AuNP (A) and AuNP (B)) and AuNP clusters (AuNPs 11-15 and AuNPs 5-10) between ds DNA molecules fixed in quasinematic layer are shown in Fig. 19. These clusters can cross-link neighboring ds DNA molecules and stabilize the spatial structure of CLCD particles, thus providing the formation of rigid ds DNA CLCD particles.

For the final verification of the assumption on linear AuNP cluster formation, structural analysis of phases formed of ds DNA CLCD treated by AuNPs was performed [98]. 


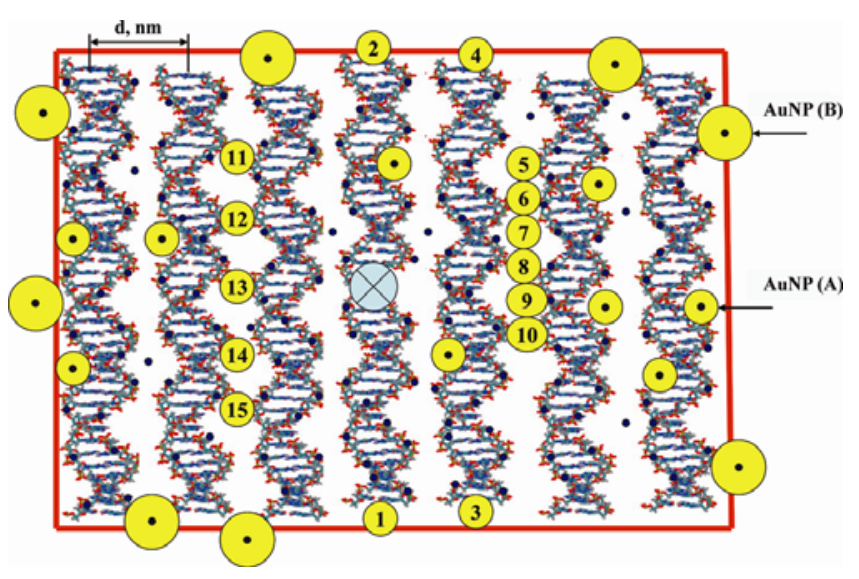

Fig. 19. The hypothetical scheme of spatial positions of different size (A, B) AuNPs near of ds DNA molecules forming a quasinematic layer [18]:

Numbers on AuNPs show various modes of location of these particles. Red rectangular frame shows osmotic pressure of PEGcontaining solution; $\mathbf{d}$ - distance between axes of neighboring DNA molecules. $\otimes-$ the rotation axis of the helical structure

The results obtained by the SAXS method and the results of calculation of possible size of AuNP clusters made by the program GNOM [99, 100] allow one to suggest a hypothetical model for fixation of
AuNPs between ds DNA molecules in quasinematic layers. According to this model (Fig. 20), initial AuNPs have average diameter (size) of about $2 \mathrm{~nm}$. These AuNPs form linear clusters with average length $13-15 \mathrm{~nm}$ and clusters with maximal length of $\sim 40-50 \mathrm{~nm}$. Formation of Au-clusters between ds DNA molecules can perturb mutual orientation of neighboring quasinematic layers [101].

The literature data describing the properties of AuNPs $[65,71]$ and the properties of ds DNA CLCD particles $[3,4]$ allow one to consider two hypotheses on the possible mechanisms of interaction between the negatively charged AuNPs with ds DNA molecules. Such interaction can be realized within the frame-work of the chemical or the physical mechanism.

The chemical mechanism means that in solutions of high ionic strength the polydentate interaction between the nitrogen-containing groups (N3 and N7 of adenine and guanine) of the nitrogen bases of the DNA molecule and AuNPs located close to it. In the fame-work of this hypothesis about the possibility of binding of AuNPs with ds DNA molecules one can consider the possible sites of fixation of AuNPs near the ds DNA molecules in the quasinematic layer.

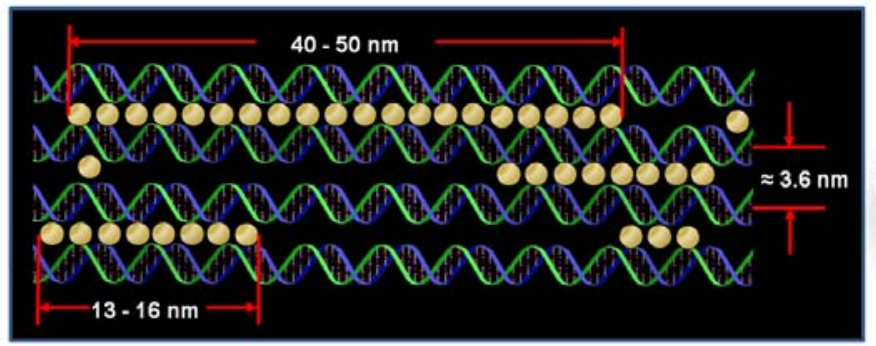

A

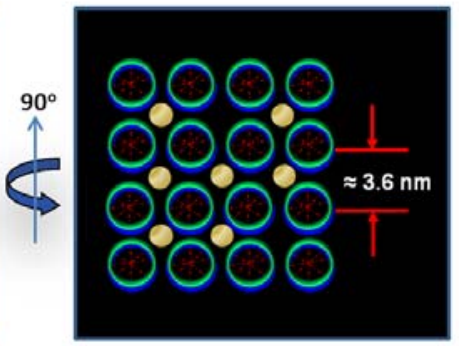

B

Fig. 20. The hypothetical model of location of linear Au-clusters in the free space between DNA molecules forming the quasinematic layers in structure of CLCD [18]: A - side view; $\mathbf{B}$ - end view

Firstly, AuNPs of any size (Fig. 19, $A$ and $B$ ) can interact with both the surface of DNA molecules and pairs of nitrogen bases of DNA end groups of the quasinematic layers, forming complexes with them (ensembles). Binding of even a small number of negatively charged AuNPs by DNA molecules (especially with the terminal groups of these molecules) causes the formation of dipoles (Fig. 19, AuNPs 1-2 and 3-4). The dipoles $(\mathrm{DNA}+$ AuNPs) in adjacent quasinematic layers will be arranged in parallel. The binding of negatively charged AuNPs, having no significant effect on strength (steric, etc.), determines the tendency of neighboring DNA molecules toward the parallel arrangement and can cause changes in the contributions (including anisotropic contributions to the van der Waals interaction) defining the helical twist of neighboring quasinematic layers of DNA molecules. In this case, the helical twist of neighboring quasinematic layers will be broken and 
the twist angle between these layers $\left(\sim 0.5^{\circ}\right)$ may apply to the 0 value, which is equivalent to the untwisting of the cholesteric helical structure of the CLCD particles, followed by the disappearance of the abnormal band in the CD spectrum of the these particles. The AuNPs, the size of which is comparable with the free space between the ds DNA molecules in the quasinematic layers (Fig. 19, A), can diffuse between these molecules. Effective interaction between adjacent AuNPs can be realized through the DNA molecule. In this case, there is an opportunity not only for the spatial fixation of individual AuNPs, but also for the formation of different linear ensembles from neighboring AuNPs (Fig. 19, AuNPs 5-10 and AuNPs 11-15). The spatial structure of the AuNPs may be deformed, adjusting to the spatial parameters of the ds DNA molecules to maximize interaction. To ensure the interaction of the DNA with the negatively charged AuNPs, the DNA secondary structure can become disturbed and/or the water molecules may be displaced from the hydrate shell of DNA.

The physical mechanism is based on binding (concentrating) of negatively charged AuNPs on ds DNA molecules in aqueous solution when AuNPs are polarized in the electrostatic field of the DNA molecule. As for details of mechanism of interaction of negatively charged AuNPs with ds DNA molecules under high ionic strength of solution, one can add that the phenomenon of attraction between bodies carrying like charges was known since W. Thomson paper [102].

In last 20 years this phenomenon was tested for many situations theoretically and experimentally [103-110]. The physical explanation lies in charge redistribution on the two particles owing to their mutual polarization: attraction arises as the particles approach each other. Keeping this in mind, the system $(\mathrm{DNA}+\mathrm{AuNP})$ was carefully studied in a few papers [111-113]. It was shown that negatively charged AuNPs are undoubtedly be bound to free, linear ds DNA molecules in water-salt solutions of high ionic strength. It was shown that negatively charged AuNPs are undoubtedly be bound to free, linear ds DNA molecules in water-salt solutions of high ionic strength.

Thus, there are good reasons to suppose that in solutions of high ionic strength, negatively charged AuNPs can interact with the ds DNA molecules. The binding of negatively charged AuNPs with ds DNA molecules under any mechanism is dynamic in nature and AuNPs can diffuse along DNA molecules, being fixed in the sites of the most durable binding.
It can be assumed that the efficiency of the AuNPs interaction with ds DNA molecules depends on several factors: the sequence of nitrogen bases in the DNA molecules, especially the secondary structure, and the size (diameter) and shape of the AuNPs.

The incorporation of AuNPs into quasinematic layers of ds DNA CLCD particles and their spatial rdering between these molecules in quasinematic layers must be transformed by this or that way into the changes in the total energy of interaction between neighboring ds DNA molecules. The dipoles of neighboring (DNA-AuNPs) complexes tend to be arranged in parallel mode, and it can induce a change in the helical twist of neighboring quasinematic layers. In this case, the twist angle between the layers may turn to zero, which is equivalent to the untwisting of the cholesteric structure of dispersion particles at AuNPs doping.

The formation of linear clusters of AuNP in the free space between the ds DNA molecules results in the interaction between them being realized via AuNPs. An integrated structure [...DNA $(\mathrm{AuNP})_{n} \ldots$ DNA $\left.(\mathrm{AuNpAu})_{m} \ldots \mathrm{DNA} \ldots\right](n, m=1,2$, etc.) is formed and includes nearly the all of the DNA molecule of a single particle. Physical linking of neighboring ds DNA molecules in quasinematic layers occurs (it is similar to gel-formation). Furthermore, the presence of single AuNPs and extended clusters of AuNPs in the quasinematic layers of DNA molecules leads to reduced solubility of the formed structure. The integrated structure, having a very high-molecular mass, is incompatible with the water-salt solution of PEG. The stability of this structure is determined not by the properties of the PEG solution, but by the number and properties of the individual AuNPs and Au-clusters in its composition. This means that the transition of the DNA CLCD particles from the "liquid" state to the "rigid" (metalized, insoluble) state happens. The transition of ds DNA CLCD particles to the rigid state opens up the possibility for the immobilization of rigid particles on the surface of the nuclear membrane filter and the study of their morphology by AFM.

Fig. 21 shows the various images of the rigid particle formed as a result of the processing of DNA CLCD particles by AuNPs. The height of the ds DNA CLCD particles produced as a result of physical linking of neighboring DNA molecules that are fixed in the quasinematic layers of clusters from AuNPs is about $400 \mathrm{~nm}$. 

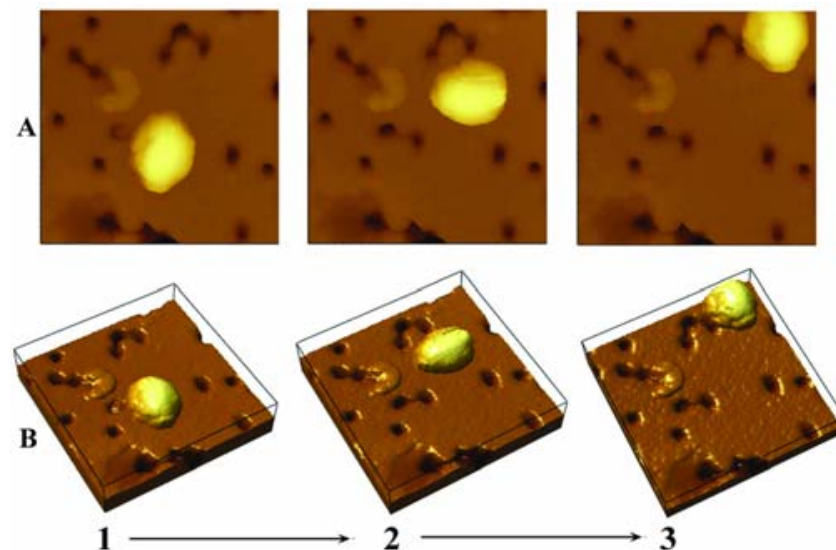

Fig. 21. 2-D (A) and 3-D (B) AFM images of three successive positions on the surface of a nuclear membrane filter (PETF) of the single metallized particle obtained as a result of treatment of DNA CLCD particles with gold nanoparticles [18]:

Metallized DNA CLCD particle move over the surface of a membrane filter during the approach of an AFM cantilever (positions $1 \rightarrow 2 \rightarrow 3$ ) and can be fixed at certain places on the filter

The principal difference between rigid particles of ds DNA derived by means of the physical linking and rigid particles prepared as result of the chemical gelation inside the particles is that they are weakly bound to the surface of the nuclear membrane filter. Indeed, Fig. 21 shows that metallized ds DNA CLCD particle, i.e., DNA CLCD particle treated with AuNPs, move over the surface of a membrane filter during the approach of an AFM cantilever and can be fixed at certain places on the filter. This movement of metallized ds DNA CLCD particles may be of interest from the nanotechnology point of view because it opens opportunities for the creation of a matrix with specific properties.

The above results showing that extremely low concentrations of AuNPs (a few AuNPs on a ds DNA molecule corresponds to a total concentration of AuNPs of $10^{12}$ particle $/ \mathrm{ml}$ ) causes a disturbance of the spatial structure of the ds DNA CLCD particle are of great interest from a biological point of view.

In conclusion one can say that although the produced integrated (gel-like) ds DNA structures have almost constant spatial parameters, they differ not only in the content of chemically important substances or BACs, but also in their specific properties. Considered approaches allow one to obtain the "rigid" ds DNA
CLCD particles with different properties, which can find various (sometimes unexpected) applications.

\section{Conclusions}

A general physicochemical approach to transformation of the ds DNA cholesteric liquidcrystalline (CLCD) dispersion particles to "rigid" state was formulated. This approach takes into account very low solubility of high-molecular mass, integrated, gellike structure that includes all ds DNA molecules ordered in quasinematic layers of the spatial structure of the CLCD particles. The main variants of decrease the solubility of ds DNA molecules and induction of the integrated structure, which is incompatible with polymer containing solution, are exemplified. The "liquid" character of ds DNA packing in dispersion particles disappears, and particles with a "rigid" structure ("rigid" particles) are appeared. It opens up a possibility for immobilization of the "rigid" particles on a surface of nuclear membrane filter and evaluation of their physical parameters. A new possibility for formation of "rigid" ds DNA particles is offered by the nanotechnological approach. Binding of negatively charged Au-nanopartices to ds DNA molecules ordered in the CLCD particles (in a high salt solution) initiates transformation of "liquid" structure of dispersion particles into "rigid" state. These "metalized" DNA particles are weakly bound to the surface of membrane filter. This enables their controlled movement over the filter surface and fixation at the required sites on the filter, which can be of nanotechnological importance.

Acknowledgements: The support from the Russian Science Foundation (Project no. 16-15-00041) is gratefully acknowledged.

\section{References}

1. Stanley C.B., Hong H., Strey H.H. DNA cholesteric pitch as a function of density and ionic strength. Biophys. J., 2005, 89 (4), 2552-2557.

DOI: $10.1529 /$ biophysj.105.064550.

2. Goldar A., Thomson H., Seddon J.M. Structure of DNA cholesteric spherulitic droplet dispersions. J. Phys.: Condens. Matter, 2008, 20 (3), 035102.

DOI: $10.1088 / 0953-8984 / 20 / 03 / 035102$.

3. Yevdokimov Yu.M., Salyanov V.I., Skuridin S.G. Nanostructure and nanoconstructions based on DNA. Moscow : Science Press, 2010, 256 p. (in Russ.). 
4. Yevdokimov Yu.M., Skuridin S.G., Salyanov V.I., Bykov V.A., Palimbo M. Structural DNA nanotechnology : liquid-crystalline approach. Applied synthetic biology / Ed. by J.N. Govil. New York: Studium Press LLC, 2014, 4, 32-380.

5. Livolant F.J. Supramolecular organization of doublestranded DNA molecules in the columnar hexagonal liquid crystalline phase. An electron microscopic analysis using freeze-fracture methods. Mol. Biol., 1991, 218 (1), 165-181.

DOI: $10.1016 / 0022-2836(91) 90882-7$.

6. Livolant F., Levelut A.M., Doucet J., Benoit. J.P. The highly concentrated liquid-crystalline phase of DNA is columnar hexagonal. Nature, 1989, 339 (6227), 724-726. DOI: $10.1038 / 339724 a 0$.

7. Livolant F., Leforestier A. Condensed phases of DNA: structures and phase transitions. Prog. Polym. Sci., 1996, 21 (6), 1115-1164.

DOI: $10.1016 /$ S0079-6700(96)00016-0.

8. Yevdokimov Yu.M., Skuridin S.G., Salyanov V.I., Semenov S.V., Sol'ev P.N, Valuev-Elliston V.T., Vereshchagin F.V., Chulkov D.P., Kompanets O.N. On the possibility of determining anthracycline antibiotics in aqueous solutions using optical analytical system (biosensor). Opt. Spectrosc., 2017, 122 (2), 194-201.

DOI: $10.1134 / \mathrm{S} 0030400 \mathrm{X} 17020096$

9. Chandrasekhar S. Liquid Crystals. $2^{\text {nd }}$ ed. Cambridge : Cambridge University Press, 1992, 480 p.

DOI: $10.1017 / \mathrm{CBO} 9780511622496$.

10. Papkov S.P., Kulichikhin V.G. Liquid crystalline state of polymers. Moscow : Khimiya, 1977, 240 p. (in Russ.)

11. Chilaya G.S., Lisetskii L.N. Helical twist in cholesteric mesophases. Sov. Phys. Usp., 1981, 24 (6), 496-510.

DOI: 10.1070/PU1981v024n06ABEH004849.

12. Kornyshev A.A., Leikin S., Malinin S.V. Chiral electrostatic interaction and cholesteric liquid crystals of DNA. Eur. Phys. J. E, 2002, 7 (1), 83-93.

DOI: $10.1140 /$ epje/i200101159.

13. Semenov S.V., Yevdokimov Yu.M. Circular dichroism of DNA liquid-crystalline dispersion particles. Biophysics, 2015, 60 (2), 188-196.

DOI: $10.1134 / \mathrm{S} 0006350915020177$.

14. Yevdokimov Yu.M., Salyanov V.I., Skuridin S.G., Semenov S.V., Kompanets O.N. The CD spectra of double-stranded DNA liquid crystalline dispersions. New York : Nova Science Publishers, 2011, 103 p.

15. Yevdokimov Yu.M., Skuridin S.G., Semenov S.V., Dadinova L.A., Salyanov V.I., Kats E.I. The reentrant cholesteric phase of DNA. J. Biol. Phys., 2017, 43 (1), 45-68. DOI: 10.1007/s10867-016-9433-4.

16. Yevdokimov Yu.M., Salyanov V.I., Shtykova E.V., Kats E.I., Khlebtsov N.G., Skuridin, S.G. Structural nanotechnology of nucleic acids: designing "liquid" and "rigid" DNA nanoconstructions. Her. Russ. Acad. Sci., 2014, 84 (4), 252-264.

DOI: $10.1134 / \mathrm{S} 1019331614040066$.

17. Yevdokimov Yu.M., Salyanov V.I., Kondrashina O.V., Borshevsky V.I., Semenov S.V., Gasanov A.A., Reshetov I.V., Kuznetsov V.D., Nikiforov V.N., Akulinichev S.V., Mordovskoi M.V., Potashev S.I., Skorkin V.M. Particles of liquid-crystalline dispersions formed by (nucleic acid-rare earth element) complexes as a potential platform for neutron capture therapy. Int. J. Biol. Macromol., 2005, 37 (4), 165-173.

DOI: $10.1016 / \mathrm{j}$.ijbiomac.2005.10.001.

18. Yevdokimov Yu.M., Salyanov V.I., Skuridin S.G., Shtykova E.V., Khlebtsov N.G., Kats E.I. Physicochemical and nanotechnological approaches to the design of "rigid" spatial structures of DNA. Russ. Chem. Rev., 2015, 84 (1), 27-42.

DOI: $10.1070 / R C R 4454$.

19. Yevdokimov Yu.M., Salyanov V.I., Akulinichev S.V., Skorkin V.M., Spirin, P.V., Orlova N.N., Popenko V.I., Prassolov V.S. Novel biomaterial for NCT - "rigid" particles of (DNA-Gadolinium) liquid-crystalline dispersions. J. Biomater. Nanobiotechnol., 2011, 2 (3), 281-292.

DOI: $10.4236 /$ jbnb.2011.23035.

20. Li L., Yang J., Wu X., Sun C., Zhou G. Study on the co-luminescence effect of terbium-gadoliniumnucleic acids-cetylpyridine bromide system. $J$. Lumin., 2003, 101 (1), 141-146.

DOI: $10.1016 / \mathrm{S} 0022-2313(02) 00406-4$.

21. Haertléa T., Augustyniak J., Guschlbauer W. Is $\mathrm{Tb}^{3+}$ fluorescence enhancement only due to binding to single stranded polynucleotides? Nucl. Acids Res., 1981, 9 (22), 6191-6197.

DOI: $10.1093 /$ nar/9.22.6191.

22. Belyakov V.A., Orlov V.P., Semenov S.V., Skuridin S.G., Yevdokimov Yu.M. Comparison of calculated and observed CD spectra of liquid crystalline dispersions formed from double-stranded DNA and from DNA complexes with coloured compounds. Liquid Cryst., 1996, 20 (6), 777-784.

DOI: $10.1080 / 02678299608033172$.

23. Yevdokimov Yu.M., Salyanov V.I., Kondrashina O.V., Lagutina M.A., Gasanov A.A., Nikiforov V.N., Borshchevskii V.I., Dembo K.A., Reshetov I.V. Liquid crystalline dispersions of DNA complexes with gadolinium as a possible basis for neutron trapping therapy. Dokl. Biochem. Biophys., 2005, 402, 240-242. DOI: $10.1007 / \mathrm{s} 10628-005-0081-z$.

24. Akulinichev S.V., Skorkin V.M., Nikiforov V.N., Salyanov V.I., Evseev A.I., Kondrashina O.V., Yevdokimov, Yu.M. A new biomaterial based on the (DNA-Gd) complexes. 1. Definition of gadolinium concentration in the particles. Medical Physics, 2006, 3 (31), 64-69 (in Russ.). 
25. Akulinichev S.V., Yevdokimov Yu.M., Labeznik D.B., Plyaschkyavich M.L., Evseev A.I., Salyanov, V.I., Skorkin B.M. Biomaterial based on cholesteric liquid crystalline dispersion particles of (DNA-Gd) complex. 2. Secondary radiation from neutron capture in particles. Medical Physics, 2006, 4 (32), 54-58 (in Russ.).

26. Salyanov V.I., Evseev A.I., Popenko V.I., Gasanov A.A., Dembo K.A., Kondrashina O.V., Shtykova E.V., Yevdokimov Yu.M. Gadolinium complexes of linear and liquid-crystalline DNA. Biophysics, 2007, 52 (3), 88-292. DOI: $10.1134 /$ S0006350907030050.

27. Yevdokimov Yu.M., Salyanov V.I., Kondrashina O.V., Gasanov A.A., Shtykova E.V., Dembo K.A. Rareearth-cation-induced change in the cholesteric twisting of neighboring nucleic acid molecules. J. Exp. Theor. Phys., 2007, 104 (3), 499-507.

DOI: $10.1134 / \mathrm{S} 1063776107030168$.

28. Yevdokimov Yu.M., Salyanov V.I., Shtykova E.V., Dembo K.A., Volkov V.V., Spirin P.V., Slusheva A.S., Prassolov V.S. A transition in DNA molecule's spatial ordering due to nano-scale structural changes. Open Nanosci. J., 2008, 2 (1), 17-28.

DOI: $10.2174 / 1874140100802010017$.

29. Shtykova E.V., Volkov V.V., Salyanov V.I., Yevdokimov Yu.M. SAXS-data-based structural modeling of DNA-gadolinium complexes fixed in particles of cholesteric liquid-crystalline dispersions. Eur. Biophys. J., 2010, 39 (9), 1313-1322.

DOI: $10.1007 / \mathrm{s} 00249-010-0584-0$.

30. Popenko V.I., Leonova O.G., Salyanov V.I., Orlova N.N., Spirin P.V., Prasolov V.S., Evdokimov, Yu.M. Dynamics of penetration of "rigid" nanostructures of double-stranded DNA complexed with gadolinium into CHO cells. Molecular Biology, 2013, 47 (5), 743-750. DOI: $10.1134 / \mathrm{S} 0026893313050178$.

31. Nikiforov V.N., Kuznetsov V.D., Yevdokimov Yu.M., Irkhin V.Yu. Magnetic properties of $\mathrm{Gd}^{3+}$ ions in the spatially distributed DNA molecules. J. Magn. Magn. Mat., 2014, 386 (November), 338-341.

DOI: $10.1016 / \mathrm{j} . j m m m .2014 .06 .008$.

32. Akine Y., Tokita N., Matsumoto, T., Oyama H., Egawa S., Aizawa, O. Radiation effect of gadoliniumneutron capture reactions on the survival of Chinese hamster cells. Strahlenther. Onkol., 1990, 166 (12), 831-833. PubMed: 2267661.

33. Allen B.J., McGregor B.J., Martin R.F. Neutron capture therapy with gadolinium-157. Strahlenther. Onkol., 1989, 165 (2-3), 156-158. PMID: 2494720.

34. Greenwood R.C., Reich C.W., Baader H.A., Koch H.R., Breitig D., Schult O.W.B., Fogelberg B., Bäcklin A., Mampe W., von Egidy T., Schreckenbach K. Collective and two-quasiparticle states in ${ }^{158} \mathrm{Gd}$ observed through study of radiative neutron capture in ${ }^{157}$ Gd. Nucl. Phys. A, 1978, 304 (2), 327-428.

DOI: $10.1016 / 0375-9474(78) 90242-7$.

35. Saha T.K., Jono K., Ichikawa H., Fukumori Y. Preparation and evaluation of glutaraldehyde cross- linked chitosan microspheres as a gadolinium reservoir for neutron-capture therapy. Chem. Pharma. Bull., 1988, 46 (3), 537-539.

DOI: $10.1248 / \mathrm{cpb} .46 .537$.

36. Tokumitsu H., Ichikawa H., Fukumori Y. Chitosangadopentetic acid complex nanoparticles for gadolinium neutron-capture therapy of cancer: preparation by novel emulsion-droplet coalescence technique and characterization. Pharm. Res., 1999, 16 (12), 1830-1835.

DOI: $10.1023 / \mathrm{A}: 1018995124527$.

37. Leclercq Q.F., Cohen-Ohana M., Mignet N., Sharbati A., Herscovici J., Sherman D., Byk G. Design, synthesis, and evaluation of gadolinium cationic lipids as tools for biodistribution studies of gene delivery complexes. Bioconjug. Chem., 2003, 14 (1), 112-119. DOI: $10.1021 / \mathrm{bc} 025567 \mathrm{e}$.

38. Tokumitsu H., Ichikawa H., Fukumori Y., Block L.H. Preparation of gadopentetic acid-loaded chitosan microparticles for gadolinium neutron-capture therapy of cancer by a novel emulsion-droplet coalescence technique. Chem. Pharm. Bull. (Tokyo), 1999, 47 (6), 838-842. PMID: 10399838.

39. Yevdokimov Yu.M., Salyanov V.I., Nechipurenko Yu.D., Skuridin S.G., Zakharov M.A., Spener F., Palumbo M. Molecular constructions (superstructures) with adjustable properties based on double-stranded nucleic acids. Molecular Biology, 2003, 37 (2), 293-306.

DOI: $10.1023 / \mathrm{A}: 1023358008003$.

40. Yevdokimov Yu.M., Salyanov V.I.; Gedig E., Spener F.F. Formation of polymeric chelate bridges between double-stranded DNA molecules fixed in spatial structure of liquid-crystalline dispersions. FEBS Lett., 1996, 392 (3), 269-273.

DOI: $10.1016 / 0014-5793(96) 00826-5$.

41. Gianni L., Corden B.J., Meyers E. The biochemical basis of anthracycline toxicity and antitumor activity. Reviews in biochemical toxicology / Ed. by E. Hodgson, J.R. Bend, R.M. Philpot. New York : Elsevier Biomedical, 1983, 1-82.

42. Greenaway F.T., Dabrowiak J.C. The binding of copper ions to daunomycin and adriamycin. J. Inorg. Biochem., 1982, 16 (2), 91-107.

DOI: $10.1016 / \mathrm{S} 0162-0134(00) 80218-4$.

43. Coble H.D., Holtzclaw H.F. Chelate polymers of copper (II) various dihydroxyquinoid ligands. J. Inorg. Nucl. Chem. 1974, 36 (5), 1049-1053.

DOI: $10.1016 / 0022-1902(74) 80211-3$.

44. Garnier-Siullero A. Anthracycline and anthacenedione-based anticancer agents / Ed. by J.W. Lown. Amsterdam : Elsevier, 1988, 6, 129-161.

45. Yevdokimov Yu.M., Salyanov V.I., Buligin L.V., Dembo A.T., Gedig E., Spener F., Palumbo M. Liquid-crystalline structure of nucleic acids: effect of antracycline drugs and copper ions. J. Biomol. Struct. 
Dynamics, 1997, 15 (1), 97-105.

DOI: $10.1080 / 07391102.1997 .10508949$.

46. Wells A.F. Structural Inorganic Chemistry: 5th ed. Oxford : University Press, 1984, 1097-1148.

47. Kaneko M., Tsuchida E. Formation, characterization, and catalytic activities of polymer-metal complexes. J. Polym. Sci.: Macromol. Revs., 1981, 16 (1), 397522. DOI: $10.1002 /$ pol.1981.230160107.

48. Barthelemy-Clavey V., Maurizot J-C., Sicard Ph.J. Etude spectrophotométrique du complexe DNAdaunorubicine. Biochimie, 1973, 55 (8), 859-868. DOI: $10.1016 / \mathrm{S} 0300-9084(73) 80162-2$.

49. Hopfinger A.J., Nakata Y., Max N. Quantitave strucrure activity relationships of anthracycline antitumor activity and cardiac toxity based upon intercalation calculations. Intermolecular Forces / Ed. by B. Pullman. Dordrecht : Springer, 1981, 431-444. DOI: $10.1007 / 978-94-015-7658-127$.

50. Bell M.J.; Buchanan G.W.; Hollebone B.R.; Jones E.D. Antitumor activity at the molecular level: binding modes in anthracycline-dinucleotide complexes as determined by optical titration and magnetic circular dichroism. Can. J. Chem., 1982, 60 (3), 291-298. DOI: $10.1139 / \mathrm{v} 82-044$

51. Yevdokimov Yu.M., Skuridin S.G., Nechipurenko Yu.D., Zakharov M.A., Salyanov V.I., Kurnosov A.A., Kuznetsov V.D., Nikiforov V.N. Nanoconstructions based on double-stranded nucleic acids. Int. J. Biol. Macromol., 2005, 36 (1-2), 103115. DOI: $10.1016 /$ j.ijbiomac.2005.04.004.

52. Yevdokimov Yu.M., Salyanov V.I., Spener F., Palumbo, M. Adjustable "cross-linking" of neighboring DNA molecules in liquid-crystalline dispersions through (daunomycin-copper) polymeric chelate complexes. Int. J. Biol. Macromol., 1996, 19 (4), 247-255. DOI: 10.1016/S0141-8130(96)01134-8.

53. Zakharov M.A., Sokolovskaya L.G., Nechipurenko Yu.D., Lortkipanidze, G.B., Yevdokimov Yu.M. The formation of nanoconstructions based on doublestranded DNA molecules. Biophysics, 2005, 50 (5), 721-727. PMID: 16248157.

54. Yevdokimov Yu.M., Salyanov V.I., Skuridin S.G. Nanostructures and Nanoconstructions based on DNA. Boca Raton -London - New York : CRC Press (Taylor \& Francis Group), 2012, 250 p.

55. Yevdokimov Yu.M., Skuridin S.G., Salyanov V.I. The liquid-crystalline phases of double-stranded nucleic acids in vitro and in vivo. Liquid Cryst., 1988, 3 (11), 1443-1459.

DOI: $10.1080 / 02678298808086687$.

56. Nechipurenko Yu.D., Strel'tsov S.A., Yevdokimov Yu.M. Thermodynamic model of the formation of bridges between nucleic acid molecules in a liquid crystal. Biophysics, 2001, 46 (3), 406-413.

PMID: 11449541.
57. Nechipurenko Yu.D., Ryabokon V.F., Semenov S.V., Yevdokimov Yu.M. Thermodynamic models, describing the formation of "bridges" between of nucleic acid molecules and liquid crystals. Biophysics, 2003, 48 (4), 594-601. PMID: 14515481.

58. Nechipurenko Yu.D., Wolf A.M., Yevdokimov Yu.M. Distribution functions, describing the binding of extended ligands with DNA molecules. Possible use for cases of DNA condensation. Biophysics, 2003, 48 (5), 746-754. PMID: 14582403.

59. Ryabokon V.F., Nechipurenko Yu.D., Semenov S.V., Yevdokimov Yu.M. "Bridges" between nucleic acid molecules in liquid crystals. Description from the point of view of the adsorption theory. Liq. Cryst. and their Appl., 2003, 3, 69-78 (in Russ.).

60. NikiforovV.N., Kuznetsov V.D., Nechipurenko Yu.D., Salyanov V.I., Yevdokimov Yu.M. Magnetic properties of copper as a constituent of nanobridges formed between spatially fixed deoxyribonucleic acid molecules. JETP Lett., 2005, 81 (6), 264-266.

DOI: $10.1134 / 1.1931012$.

61. Yevdokimov Yu.M., Sytchev V.V. Nanotechnology and nucleic acids. Technologies of Living Systems, 2007, 4 (1), 3-27 (in Russ.).

62. Skuridin S.G., Yevdokimov Yu.M. DNA liquidcrystalline dispersion particles as a basis for sensitive biosensor elements. Biophysics, 2004, 49 (3), 445462. PMID: 15327206.

63. Skuridin S.G., Vereshchagin F.V., Salyanov V.I., Gusev V.M., Pavlov M.A., Kompanets O.N., Yevdokimov Yu.M. Biosensor test-system for determination of the physiological heparin concentrations. Sensor Systems, 2015, 29 (1), 84-92 (in Russ.).

64. Kazanskii K.S., Lagutina M.A., Skuridin S.G., Yevdokimov Yu.M. Nanoconstructions based on double-stranded DNA in polyethylene oxide hydrogels. Dokl. Phys. Chem., 2007, 414 (2), 147149. DOI: $10.1134 /$ S0012501607060073.

65. Louis C., Pluchery O. Gold nanoparticles for physics, chemistry and biology. London : Imperial College Press, 2012, 395 p.

66. Hegmann T., Qi H., Marx V.M. Nanoparticles in liquid crystals: synthesis, self-assembly, defect formation and potential applications. J. Inorg. Organomet. Polym. Mater., 2007, 17 (3), 483-508. DOI: $10.1007 / \mathrm{s} 10904-007-9140-5$.

67. Nealon G.L., Greget R., Dominguez C., Nagy Z.T., Gallani J-L., Donnio B. Liquid-crystalline nanoparticles: hybrid design and mesophase structures. Beilstein J. Org. Chem., 2012, 8, 349-370. DOI: $10.3762 /$ bjoc.8.39.

68. Stamatoiu O., Mirzaei J., Feng X., Hegmann T. Nanoparticles in liquid crystals and liquid crystalline 
nanoparticles. Topics Curr. Chem., 2012, 318, 331393. DOI: $10.1007 / 128$ 2011_233.

69. Lagerwall J.P.F., Scalia G. A new era for liquid crystal research: applications of liquid crystals in soft matter nano-, bio- and microtechnology. Curr. Appl. Phys., 2012, 12 (6), 1387-1412.

DOI: $10.1016 /$ j.cap.2012.03.019.

70. Qi H., Hegman T. Liquid crystal-gold nanoparticle composites. Liquid Cryst. Today, 2011, 20 (4), 102114. DOI: $10.1080 / 1358314 X .2011 .610133$

71. Dykman L.A., Bogatyrev V.A., Shchyogolev S.Y., Khlebtsov N.G. Gold nanoparticles: synthesis, properties, biological application. Moscow : Nauka, 2008, 320 p. (in Russ.).

72. Schmid G., Klein N., Korste L. Large transition metal clusters. VI. Ligand exchange reactions on $\mathrm{Au}_{55}\left(\mathrm{PPh}_{3}\right)_{12} \mathrm{Cl}_{6}$ - the formation of a water soluble $\mathrm{Au}_{55}$ cluster. Polyhedron, 1988, 7 (8), 605-608.

DOI: $10.1016 / \mathrm{S} 0277-5387(00) 80366-6$.

73. Hakkinen H. Theoretical studies of gold nanoclusters in various environments. When the size matters. Gold nanoparticles for physics, chemistry and biology / Ed. by P. Louis, O. Pluchery. London : Imperial Press 2012, 233-272.

74. Saendig N., Zerbetto F. Molecules on gold. Chem. Commun., 2010, 46 (5), 667-676. DOI: 0.1039/B915580E.

75. Pichugina D.A., Mazhuga F.G., Shestakov A.F. Gold nanoparticles: acquisition, structure, properties and application. Organic and hybrid nanomaterials: trends and prospects / Eds. V.F. Razumov, M.V. Klyuev. Ivanovo : IvSU, 2013, 147-190 (in Russ.).

76. Nel A., Xia T., Madler L., Li N. Toxic potential of materials at the nanolevel. Science, 2006, 311 (5761), 622-627. DOI: $10.1126 /$ science.1114397.

77. Bus E., Prins R., van Bokhoven J.A. Origin of the cluster-size effect in the hydrogenation of cinnamaldehyde over supported Au catalysts. Catal. Commun., 2007, 8 (9), 1397-1402.

DOI: $10.1016 /$ j.catcom.2006.11.040.

78. Imura Y., Morita C., Endo H., Kondo T., Kawai T. Reversible phase transfer and fractionation of $\mathrm{Au}$ nanoparticles by $\mathrm{pH}$ change. Chem. Commun., 2010, 46 (48), 9206-9208. DOI: 10.1039/C0CC03194A.

79. Pan Y., Neuss S., Leifert A., Fischler M., Wen F., Simon U., Schmid G., Brandau W., Jahnen-Dechent W. Size-dependent cytotoxicity of gold nanoparticles. Small, 2007, 3 (11), 1941-1949.

DOI: $10.1002 / \mathrm{smll} .200700378$.

80. Weitz D.A., Lin M.Y., Sandroff C.J. Colloidal aggregation revisited - new insights based on fractal structure and surface-enhanced raman-scattering. Surf. Sci., 1985, 158, 147-164.

DOI: $10.1016 / 0039-6028(85) 90292-4$.

81. Parak W.J., Pellegrino T., Micheel C.M., Gerion D., Williams S.C., Alivisatos A.P. Conformation of oligonucleotides attached to gold nanocrystals probed by gel electrophoresis. Nano Lett., 2003, 3 (1), 33-36. DOI: $10.1021 / \mathrm{n} 1025888 \mathrm{z}$.

82. Kim T., Lee K., Gong M.S., Joo S.W. Control of gold nanoparticle aggregates by manipulation of interparticle nteraction. Langmuir, 2005, 21 (21), 9524-9528. DOI: 10.1021/la0504560.

83. Liu Y., Meyer-Zaika W., Franzka S., Schmid G., Tsoli M., Kuhn H. Gold-cluster degradation by the transition of B-DNA into A-DNA and the formation of nanowires. Angew. Chem. Int. Ed., 2003, 42 (25), 2853-2857. DOI: 10.1002/anie.200250235.

84. Mirkin C.A., Letsinger R.L., Mucic R.C., Storhoff J.J. A DNA-based method for rationally assembling nanoparticles into macroscopic materials. Nature, 1996, 382 (6592), 607-609. DOI: 10.1038/382607a0.

85. Alivisatos A.P., Johnsson K.P., Peng X., Wilson T.E., Loweth C.J., Bruchez M.P. Schultz P.G. Organization of "nanocrystal molecules" using DNA. Nature, 1996, 382 (6592), 609-611. DOI: 10.1038/382609a0.

86. Storhoff J.J., Lazarides A.A., Mucic R.C., Mirkin C.A., Letsinger R.L., Schatz G.C. What controls the optical properties of DNA-linked gold nanoparticle assemblies? Am. Chem. Soc., 2000, 122 (19), 46404650. DOI: $10.1021 /$ ja9938251.

87. Sastry M., Kumar A., Datar S., Dharmadhikari C.V., Ganesh K.N. DNA-mediated electrostatic assembly of gold nanoparticles into linear arrays by a simple dropcoating procedure. Appl. Phys. Lett., 2001, 78 (19), 2943-2945. DOI: 10.1063/1.1370993.

88. Warner M.G., Hutchison J.E. Linear assemblies of nanoparticles electrostatically organized on DNA scaffold. Nat. Mater, 2003, 2 (4), 272-277.

DOI: $10.1038 /$ nmat 853 .

89. Jones M.R., Macfarlane R.J., Lee B., Zhang J., Young K.L., Senesi A.J., Mirkin C.A. DNA-nanoparticle superlattices formed from anisotropic building blocks. Nat. Mater., 2010,9 (11), 913-917. DOI: 10.1038/nmat2870.

90. Khlebtsov B.N., Zharov V.P., Melnikov A.G., Tuchin V.V., Khlebtsov N.G. Optical amplification of photothermal therapy with gold nanoparticles and nanoclusters. Nanotechnology, 2006, 17 (20), 51675179. DOI: $10.1088 / 0957-4484 / 17 / 20 / 022$

91. Pelton M., Aizpurua J., Bryant G. Metal-nanoparticle plasmonics. Laser Photon. Rev., 2008, 2 (3), 136-159. DOI: $10.1002 /$ lpor.200810003.

92. Mayer K.M., Hafner J.H. Localized surface plasmon resonance sensors. Chem. Rev., 2011, 111 (6), 38283857. DOI: $10.1021 / \mathrm{cr} 100313 \mathrm{v}$.

93. Khlebtsov N.G., Melnikov A.G., Dykman L.A., Bogatyrev V.A. Optical properties and biomedical applications of nanostructures based on gold and silver bioconjugates. Photopolarimetry in remote sensing. NATO Science Series II: Mathematics, Physics and Chemistry / Ed. by G. Videen, Y. Yatskiv, M. Mishchenko. Dordrecht : Springer, 2004, 161, 265-308. DOI: 10.1007/1-4020-2368-5_12. 
94. Khlebtsov N.G. T-matrix method in plasmonics. J. Quant. Spectrosc. Radiat. Transfer, 2013, 123, 184-217. DOI: 10.1016/j.jqsrt.2012.12.027.

95. Lifshitz I.M., Slyozov V.V. The kinetics of precipitation from supersaturated solid solutions. J. Phys. Chem. Solids, 1961, 19 (1-2), 35-50.

DOI: $10.1016 / 0022-3697(61) 90054-3$.

96. Yevdokimov Yu.M., Salyanov V.I., Katz E.I., Skuridin S.G. Gold nanoparticle clusters in quasinematic layers of liquid-crystalline dispersion particles of double-stranded nucleic acids. Acta Naturae, 2012, 4 (4), 78-90.

https://www.ncbi.nlm.nih.gov/pmc/articles/PMC3548 176/

97. Skuridin S.G., Salyanov V.I., Popenko V.I., Shtykova E.V., Lisitsyna, E.S., Dubinskaya V.A., Bykov V.A., Yevdokimov Yu.M. Structural effects induced by gold nanoparticles in particles of cholesteric liquidcrystalline dispersion of double-stranded nucleic acids. Pharm. Chem. J., 2013, 47 (2), 71-79.

DOI: $10.1007 / \mathrm{s} 1$ 1094-013-0899-0.

98. Yevdokimov Yu.M., Skuridin S.G., Salyanov V.I., Popenko V.I., Rudoy V.M., Dement'eva O.V., Shtykova E.V. A dual effect of Au-nanoparticles on nucleic acid cholesteric liquid-crystalline particles. J. Biomater. Nanobiotechnol., 2011, 2 (4), 461-471. DOI: $10.4236 /$ jbnb.2011.24056.

99. Svergun D.I. Determination of the regularization parameter in indirect-transform methods using perceptual criteria. J. Appl. Cryst., 1992, 25 (4), 495503. DOI: $10.1107 /$ S0021889892001663.

100. Yevdokimov Yu.M., Skuridin S.G., Salyanov V.I., Popenko V.I., Shtykova E.V., Khlebtsov N.G., Shafeev G.A., Kats E.I. Gold nanoparticles influence double-stranded DNA molecules «recognition» and prevent formation of their cholesteric structure. Liq. Cryst. and their Appl., 2014, 14 (4), 5-21.

101. Yevdokimov Yu.M., Salyanov V.I., Shtykova E.V., Khlebtsov N.G., Kats E.I., Skuridin S.G. The physicochemical and nanotechnological approaches to creation of "rigid" DNA nanoconstructions. Open Nanosci. J., 2014, 8, 1-12.

DOI: $10.2174 / 1874140120140603001$.

102. Thomson W. On the mutual attraction or repulsion between two electrified sphericaconductors. Reprint of papers on electrostatics and magnetism. $2^{\text {nd }}$ ed. London: Macmillan \& Co, 1884, 128-142.

103. Soules J.A. Precise calculation of the electrostatic force between charged spheres including induction effects. Am. J. Phys., 1990, 58 (12), 1195-1199. DOI: $10.1119 / 1.16251$.
104. Grier D.G. When like charges attract: interactions and dynamics in charge-stabilized colloidal suspensions. J. Phys.: Condens. Matter, 2000, 12 (8A), 85-94. DOI: $10.1088 / 0953-8984 / 12 / 8 \mathrm{~A} / 309$.

105. Khachatourian A.V.M.,Wistrom A.O. Evaluation of the Coulomb force via the Fredholm integral equation. J. Phys. A: Math. Gen., 2000, 33 (2), 307-317.

DOI: $10.1088 / 0305-4470 / 33 / 2 / 307$.

106. Khachatourian A.V., Wistrom A.O. Size effects in aerosol electrostatic interactions. J. Colloid Interface Sci., 2001, 242 (1), 52-58.

DOI: $10.1006 /$ jcis.2001.7758.

107. Su Y.H. A numerical study of electrostatic interactions between two charged conducting droplets. Phys. Fluids, 2006, 18 (4), 042108.

DOI: $10.1063 / 1.2195463$.

108. Bichoutskaia E., Boatwright A.L., Khachatourian A., Stace A.J. Electrostatic analysis of the interactions between charged particles of dielectric materials. J. Chem. Phys., 2010, 133 (2), 024105.

DOI: $10.1063 / 1.3457157$.

109. Kolikov K., Ivanov D., Krastev G., Epitropov Y., Bozhkov S. Electrostatic interaction between two conducting spheres. J. Electrost., 2012, 70 (1), 91-96. DOI: $10.1016 /$ j.elstat.2011.10.008.

110. Lekner J. Electrostatics of two charged conducting spheres. Proc. R. Soc. A, 2012, 468 (2145), 28292848. DOI: $10.1098 /$ rspa. 2012.0133 .

111. Komarov P.V., Zherenkova L.V., Khalatur P.G. Computer simulation of the assembly of gold nanoparticles on DNA fragments via electrostatic interaction. J. Chem. Phys., 2008, 128 (12), 124909124920. DOI: $10.1063 / 1.2842070$.

112. Zherenkova L.V., Komarov P.V., Khalatur P.G., Khokhlov A.R. Nanowire self-assembly on a DNA fragment: computer simulation. Doklady Phys. Chem., 2008, 421 (2), 207-210.

DOI: $10.1134 / \mathrm{S} 0012501608080046$.

113. Yevdokimov Yu.M., Skuridin S.G., Salyanov V.I., Shtykova E.V., Dadinova L.A., Volkov V.V., Khlebtsov N.G., Komarov P.V., Kats E.I. Negatively charged gold nanoparticles "control" double-stranded DNAs spatial packing. J. Mater. Sci. and Nanotechnol., 2015, 3, 1-12.

DOI: $10.15744 / 2348-9812.3 .201$.

Поступила в редакциию 30.08.2017 2. Received 30 August 2017 